\title{
Examination of aerosol distributions and radiative effects over the Bay of Bengal and the Arabian Sea region during ICARB using satellite data and a general circulation model
}

\author{
R. Cherian ${ }^{1,2}$, C. Venkataraman ${ }^{1}$, S. Ramachandran ${ }^{3}$, J. Quaas ${ }^{2, *}$, and S. Kedia ${ }^{3}$ \\ ${ }^{1}$ Department of Chemical Engineering, Indian Institute of Technology Bombay, Powai, Mumbai, 400 076, India \\ ${ }^{2}$ Max Planck Institute for Meteorology, Hamburg, Germany \\ ${ }^{3}$ Physical Research Laboratory, Ahmedabad, 380 009, India \\ * now at: Institute for Meteorology, Universität Leipzig, Germany
}

Correspondence to: R. Cherian (cherian.ribu@gmail.com)

Received: 30 December 2010 - Published in Atmos. Chem. Phys. Discuss.: 6 May 2011

Revised: 21 January 2012 - Accepted: 23 January 2012 - Published: 1 February 2012

\begin{abstract}
In this paper we analyse aerosol loading and its direct radiative effects over the Bay of Bengal (BoB) and Arabian Sea (AS) regions for the Integrated Campaign on Aerosols, gases and Radiation Budget (ICARB) undertaken during 2006, using satellite data from the MODerate Resolution Imaging Spectroradiometer (MODIS) on board the Terra and Aqua satellites, the Aerosol Index from the Ozone Monitoring Instrument (OMI) on board the Aura satellite, and the European-Community Hamburg (ECHAM5.5) general circulation model extended by Hamburg Aerosol Module (HAM). By statistically comparing with large-scale satellite data sets, we firstly show that the aerosol properties measured during the ship-based ICARB campaign and simulated by the model are representative for the BoB and AS regions and the pre-monsoon season. In a second step, the modelled aerosol distributions were evaluated by a comparison with the measurements from the ship-based sunphotometer, and the satellite retrievals during ICARB. It is found that the model broadly reproduces the observed spatial and temporal variability in aerosol optical depth (AOD) over BoB and AS regions. However, AOD was systematically underestimated during high-pollution episodes, especially in the BoB leg. We show that this underprediction of AOD is mostly because of the deficiencies in the coarse mode, where the model shows that dust is the dominant component. The analysis of dust AOD along with the OMI Aerosol Index indicate that
\end{abstract}

missing dust transport that results from too low dust emission fluxes over the Thar Desert region in the model caused this deficiency. Thirdly, we analysed the spatio-temporal variability of AOD comparing the ship-based observations to the large-scale satellite observations and simulations. It was found that most of the variability along the track was from geographical patterns, with a minor influence by single events. Aerosol fields were homogeneous enough to yield a good statistical agreement between satellite data at a $1^{\circ}$ spatial, but only twice-daily temporal resolution, and the shipbased sunphotometer data at a much finer spatial, but dailyaverage temporal resolution. Examination of the satellite data further showed that the year 2006 is representative for the five-year period for which satellite data were available. Finally, we estimated the clear-sky solar direct aerosol radiative forcing (DARF). We found that the cruise represents well the regional-seasonal mean forcings. Constraining simulated forcings using the observed AOD distributions yields a robust estimate of regional-seasonal mean DARF of -8.6 , -21.4 and $+12.9 \mathrm{~W} \mathrm{~m}^{-2}$ at the top of the atmosphere (TOA), at the surface (SUR) and in the atmosphere (ATM), respectively, for the BoB region, and over the AS, of, $-6.8,-12.8$, and $+6 \mathrm{~W} \mathrm{~m}^{-2}$ at TOA, SUR, and ATM, respectively. 


\section{Introduction}

Atmospheric aerosols play a significant role in regional and global climate by interacting with radiation (scattering and absorption) and modifying cloud microphysical properties, although the magnitudes of these impacts remain uncertain (Forster et al., 2007). Aerosols exhibit a large spatial and temporal variability, which impacts the spatial distribution of atmospheric heating (Ramanathan et al., 2001; Chung et al., 2005; Adhikary et al., 2007). Aerosol radiative effects have been linked to emission source categories with large uncertainties that resulted from the lack of knowledge about technologies used in various emission sectors (Reddy et al., 2005; Koch et al., 2007; Verma et al., 2008). In addition, the aerosol climate impacts are complex and difficult to quantify and to observe (Forster et al., 2007; Reddy et al., 2005). Therefore, investigations of aerosol distributions, along with an understanding of emission sources, on regional scales are needed to probe uncertainties in their atmospheric abundance and climate impacts.

Recent observational and modeling studies found large spatial and seasonal heterogeneities in aerosol chemical and physical properties over the Indian region (Reddy et al., 2004; Chung et al., 2005; Adhikary et al., 2007; Verma et al., 2008; Moorthy et al., 2008; Kedia and Ramachandran, 2008; Ramachandran and Cherian, 2008). During the pre-monsoon season, from March to May, the westerly wind flow brings dry and polluted continental air masses over the Indian ocean along with clear-sky and minimal rainfall conditions. This provides an ideal situation to analyse the aerosol distributions and radiative effects. Several intense field campaigns have been conducted to characterize the aerosol distributions and its radiative effects during the north-east (NE) or winter monsoon season of JanuaryMarch (e.g. Ramanathan et al., 2001; Ramachandran and Jayaraman, 2002). A recent observational campaign, the Integrated Campaign for Aerosols, gases and Radiation Budget (ICARB), was conducted over the BoB and AS region during 18 March to 10 May 2006 (Moorthy et al., 2008, 2009; Kedia and Ramachandran, 2008; Kedia et al., 2010), termed the pre-monsoon season, which precedes the south-west (SW) or summer monsoon. The presence of significant spatiotemporal variations in aerosol loading (Moorthy et al., 2008; Kedia and Ramachandran, 2008) resulted in large spatial heterogeneities in the aerosol forcing and atmospheric heating patterns during this campaign (Moorthy et al., 2009; Kedia et al., 2010).

General circulation models (GCM) simulate the processes of emission, chemical and physical transformations, removal mechanisms, transport, and radiative impact of aerosols. The simulated aerosol properties and their climate effects exhibit large uncertainties (Textor et al., 2006; Forster et al., 2007) from the often inadequate representation of aerosol-related processes in climate models and inaccuracies in aerosol emission estimates (Textor et al., 2006). In previous stud- ies, the models were found to underestimate the measured AODs by a factor of 2 over the Indian region (Reddy et al., 2004; Verma et al., 2008) and by a factor of 1.5 when considering the entire Asian region (Adhikary et al., 2007; Kinne et al., 2006). With the large spatial and temporal variability in aerosol distributions, model comparison studies with insitu and satellite observations become valuable for studying aerosol climate effects over the Indian region.

The reported aerosol radiative forcing during ICARB was estimated by using simultaneously ground-based measurements of AOD and surface mass concentrations at point locations (Moorthy et al., 2009; Kedia et al., 2010). The uncertainties in such estimates could arise from the following assumptions: model atmosphere, surface albedo, gaseous (molecular) scattering and absorption, aerosol optical and radiative properties, location and season. It has been estimated these calculations exhibit about $10 \%$ variation taking into consideration the above-mentioned causes of uncertainties (e.g. Bellouin et al., 2004; Ramachandran, 2005). In addition, the mixing state of aerosols plays an important role in modifying their optical properties and consequently their radiative forcing. In the continental outflow from India mineral dust aerosols typically mix with anthropogenic compounds (Lawrence and Lelieveld, 2010; Cherian et al., 2010), which can strongly influence the radiative forcing compared to single-species, i.e. externally mixed particles (e.g. Jacobson, 2001) as used in previous estimates (Moorthy et al., 2009; Kedia et al., 2010). Even though measurementbased aerosol radiative forcing estimates substantially improved the understanding of aerosol radiative effects over the $\mathrm{BoB}$ and AS region, these studies are limited by their relatively short duration and small spatial coverage. It remains difficult to characterize the large spatial and temporal variations of aerosol properties and hence to estimate their radiative forcing. Therefore, a constrained, spatially and temporally resolved, regional aerosol radiative forcing estimate is needed for BoB and AS by integrating model results with measurements.

In this study, we examine whether ICARB observations are representative of impact over the entire northern Indian Ocean during the pre-monsoon season. The columnar aerosol distributions are estimated using the European Centre for Medium-Range Weather Forecasts (ECMWF)Hamburg (ECHAM, version 5.5) GCM combined with the Hamburg Aerosol Model (HAM). The large-scale datasets from the ECHAM5.5-HAM model and the MODIS satellite data were used to assess the representativeness of the ICARB ship-based observations. An analysis of the modelsimulated aerosol distributions in comparison to measurements was carried out in this study using the observations from ships and satellites during the ICARB period. The model-simulated fine and coarse mode AODs were compared to satellite retrievals (MODIS) and used to estimate the columnar aerosol type and size distributions. We also present a constrained estimate of the clear-sky direct aerosol 
radiative forcing in the shortwave (SW) spectrum at the top of the atmosphere (TOA), at the surface (SUR) and in the atmosphere (ATM).

\section{Model description}

\subsection{The aerosol-climate model ECHAM5.5-HAM}

Simulations of the atmospheric circulation were carried out using the ECHAM5.5 GCM (Roeckner, 2003) with a horizontal resolution of $\mathrm{T} 63$ (about $1.8^{\circ} \times 1.8^{\circ}$ ) and a vertical resolution of 31 levels (extended from the surface to $10 \mathrm{hPa}$ ) combined with the aerosol module HAM (Stier et al., 2005). The main components of HAM are the microphysical module M7 (Vignati et al., 2004), an emission module, a sulfate chemistry scheme (Feichter et al., 1996), a deposition module, and a radiative transfer module (Stier et al., 2006). The aerosol components considered in HAM are sulfate, black carbon (BC), organic carbon (OC), sea salt and mineral dust (Stier et al., 2005). The microphysical module of HAM predicts the evolution of an ensemble of seven internally mixed lognormal aerosol modes. The modes were composed either of compounds with no or low solubility, henceforth denoted as insoluble mode, or by an internal mixture of insoluble and soluble compounds, henceforth denoted as soluble mode (Stier et al., 2005). The size ranges considered are below $0.005 \mu \mathrm{m}$ dry particle number median radius $(r)$ for the nucleation mode, $r$ between 0.005 and $0.05 \mu \mathrm{m}$ for the Aitken mode, $r$ between 0.05 and $0.5 \mu \mathrm{m}$ for the accumulation mode, and $r$ above $0.5 \mu \mathrm{m}$ for the coarse mode (Stier et al., 2005).

Aerosol optical properties (single scattering albedo, extinction cross section, and asymmetry factor) are precalculated explicitly from Mie theory (Toon and Ackerman, 1981) and archived in a look-up table for a wide range of aerosol size distributions and refractive indices (Stier et al., 2005), and for 24 solar spectral bands (ranging from $0.25 \mu \mathrm{m}$ to $4 \mu \mathrm{m})$. At each time step of the simulation, the aerosol optical properties were extracted from the look-up table for each mode as a function of the Mie size parameter $(x=2 \pi r / \lambda$, where $r$ is the number median radius of the lognormal mode and $\lambda$ is the wavelength) and of the real and imaginary parts of the refractive index. For internally mixed particles, the refractive index was calculated as a volume-weighted average of the refractive indices of all components present in the mode, including aerosol water (Stier et al., 2005).

\subsection{Estimation of radiative forcing}

In ECHAM5.5-HAM, the instantaneous short wave direct aerosol radiative forcing (DARF $(\Delta F), \mathrm{W} \mathrm{m}^{-2}$ ) was computed as the difference in the clear-sky net radiative fluxes, with and without the radiative properties of the total aerosols (Stier et al., 2007). Adjustment of stratospheric temperatures can be neglected in the forcing calculations (Stier et al., 2007). The DARF at TOA and SUR was estimated as the change in the net (downward minus upward) flux with and without the presence of aerosols in the atmosphere as:

$$
\begin{aligned}
\Delta F_{\text {TOA, SUR }} & =\Delta F_{\text {WITH AEROSOL TOA, SUR }} \\
& -\Delta F_{\text {WITHOUT AEROSOL TOA, SUR }}
\end{aligned}
$$

The DARF within the atmosphere $\left(\Delta F_{\text {ATM }}\right)$ was estimated as the difference between the radiative forcing at TOA and SUR as:

$\Delta F_{\mathrm{ATM}}=\Delta F_{\mathrm{TOA}}-\Delta F_{\mathrm{SUR}}$

The $\Delta F_{\text {ATM }}$ indicates the amount of radiative flux (energy) absorbed by the aerosols within the atmosphere.

\section{Data sets}

\subsection{ICARB cruise measurements}

AOD measurements were made using a handheld sunphotometer instrument during the ICARB cruise expedition, conducted on the Oceanographic Research Vessel Sagar Kanya during 18 March to 10 May 2006 (Kedia and Ramachandran, 2008). The first phase of ICARB was conducted over the BoB during the period from 18 March to 12 April 2006 and the second phase of ICARB was conducted over the AS during the period from 18 April to 10 May 2006. About 40 observations were made each day at 15 min interval from 08:00 Local Standard Time (LST) to 17:00 LST in a moving frame over the ocean during clear sky conditions (Kedia and Ramachandran, 2008).

\subsection{MODIS and OMI data}

The daily Level 3 MODIS (collection V005) global $1^{\circ} \times 1^{\circ}$ gridded AOD and fine mode fraction (FMF) (Remer et al., 2005) values at $550 \mathrm{~nm}$ from both Terra (MOD08_D3) and Aqua (MYD08_D3) satellites were obtained during the ship cruise period for clear-sky pixels. Where less than 20 valid retrievals (optical depth pixel counts less than 20) were available in a $1^{\circ} \times 1^{\circ}$ grid-box (i.e. where cloudy skies are prevalent), AODs were weighted down (multiplied by a factor of 0.7 ) to avoid the potentially large influences of satellite retrieval errors such as cloud contamination, or domination by aerosol swelling in large relative humidities around clouds. The factor 0.7 is estimated as the average ratio of number of valid retrievals to the median of number of valid retrievals (20) during the cruise days. When AOD values are aggregated to the $1^{\circ} \times 1^{\circ}$ grid, these discrepancies might otherwise be propagated into larger biases (Kahn et al., 2007). In order to evaluate multi-year model-simulated AODs, the daily mean level 3 MODIS derived AODs at $550 \mathrm{~nm}$ from both Terra and Aqua satellites were used for the pre-monsoon season (March-May) during the 2001 to 2006 period. The daily Level 3 global $1^{\circ} \times 1^{\circ}$ gridded UV aerosol index (AI) from the Aura OMI sensor (http://gdata1.sci.gsfc.nasa.gov/ 
daac-bin/G3/gui.cgi?instance_id=omi) were analysed during 18 March-10 May 2006 to study the dust source locations relevant to the $\mathrm{BoB}$ and $\mathrm{AS}$ regions. $\mathrm{UV}$ AI is the difference between the observed and model estimated absorbing and non absorbing spectral radiances at 360 and $331 \mathrm{~nm}$ (http: //disc.sci.gsfc.nasa.gov/PIP/shtml/aerosol_index.shtml). AI is a useful qualitative indicator for tracking the presence of absorbing and elevated aerosols, such as biomass burning plumes and dust aerosols.

\section{Simulation setup and approach}

In this section we briefly report the aerosol emission inventory details and the experiments performed within this study. Aerosol emissions, based on the AEROCOM emission inventory (Dentener et al., 2006) of the year 2000, combined with regional emission inventories available over India (Reddy and Venkataraman, 2002; Venkataraman et al., 2005,2006 ) were used for biofuel, fossil fuel, industry and wild fire emission categories. $\mathrm{SO}_{2}$ emissions include volcanoes (Andres and Kasgnoc, 1998), vegetation fires, industry, fossil fuel and biofuel (Cofala et al., 2005). In this study, fossil fuel emissions over the Indian region were projected from base year 1999 (Reddy and Venkataraman, 2002) to the year 2006 using International Energy Agency (IEA) fuel consumption data. Emissions from residential cooking with biofuels (Venkataraman et al., 2005) were projected to 2006 using population data, while those from agricultural residue burning were directly used from Venkataraman et al. (2006). Except for DMS, $97.5 \%$ of all sulfuric emissions are assumed to be in the form of $\mathrm{SO}_{2}$ and $2.5 \%$ in the form of primary sulfate particles following Dentener et al. (2006). The dust and sea salt emissions were calculated online (Tegen et al., 2002; Schulz et al., 2004) using the ECHAM5.5 $10 \mathrm{~m}$ wind speed.

For the experiment, a model spin-up of three months was performed to initialize aerosol fields, and continued with a simulation of the March-May 2006 period for analysis. The large scale meteorology was constrained by nudging the model winds to 6-hourly ECMWF analysis meteorological fields (Simmons and Gibson, 2000). The nudged simulations allow for a fair comparison of modelled parameters with the field campaign measurements.

Additionally, a multi-year model simulation (2001-2005) was carried out to determine the representativeness of the model-simulated AOD distributions and radiative forcings over BoB and AS during the pre-monsoon season of a specific year. This simulation period covers the time frame for which most of the observation-based aerosol radiative forcing estimates over the $\mathrm{BoB}$ and $\mathrm{AS}$ regions were reported in literature (e.g. Satheesh et al., 2006; Vinoj et al., 2004). The anthropogenic emissions were kept constant (at 2000 level) in the multi-year simulation. The fossil fuel and biofuel emissions are annual-mean values $\left(\mathrm{Gg} \mathrm{yr}^{-1}\right)$, while monthly emissions were used for forest burning and crop residue burning sectors. The spatial resolution used for the emission dataset matches the model's horizontal resolution (T63). The large-scale meteorological parameters were nudged using the 6-hourly ECMWF reanalysis data in the multi-year simulation.

\section{Results and discussion}

\subsection{Spatio-temporal variability of AOD in model simulation and observations}

The model-simulated daily mean AODs were compared to AOD from ship-based remote sensing observations (Kedia and Ramachandran, 2008) and MODIS-derived Terra and Aqua satellite combined AOD values from 18 March to 10 May 2006 (Fig. 1). Model outputs were sampled along the cruise track to obtain daily-mean AOD at $550 \mathrm{~nm}$ matching the location and time periods of the cruise observations. AOD values derived from MODIS Terra and Aqua combined observations agree rather well in terms of variability ( $R=0.85$, see Tables 1 and 2$)$ with the sun photometer measured AOD values during ICARB period (Kedia and Ramachandran, 2008). ECHAM5.5-HAM simulated AOD variability agrees well with in-situ and satellite observations over the AS legs $(R=0.88$ and $R=0.77$, see Tables 1 and 2) but the AOD was systematically underpredicted by up to a factor of 3 in high pollution episodes (24 March, 1, 2, 8 and 12 April) over the BoB legs (biases of -0.13 and -0.10 compared to the sunphotometer and MODIS, respectively; Table 2). Variability, however, still was relatively well simulated ( $R=0.68$ and $R=0.75$, compared to the sunphotometer and MODIS, respectively; Table 2 and Fig. 1). The difference in the AODs estimated by ship-based measurements and satellite measurements, and model-simulated AODs could arise from the sampling time difference between the three systems (Sun photometer AOD was the mean of AODs measured from 08:00 LST to 17:00 LST and MODIS AOD was the mean of 10:30 and 13:30 LST AODs, while model AOD was the 24-h average value). However, since MODIS retrievals of $\mathrm{AOD}$ at a $1^{\circ} \times 1^{\circ}$ resolution correspond well to the single-column ship-based sunphotometer measurements, and since also the sparse temporal sampling of MODIS (up to twice daily, depending on cloudiness) agrees well with the daytime-averages of the ship-based observations, we conclude that the AOD variability for these oceanic regions and season was low at temporal scales of less than 1 day, and at horizontal scales of less than 1 degree.

The impact of aerosol swelling in high relative humidities during cloudy conditions, or of cloud contamination for both MODIS and sunphotometer observations, was examined with the help of the model by comparing the AOD values sampled at cloud-free days to the ones averaged over all days. Grid points with MODIS optical depth pixel counts 


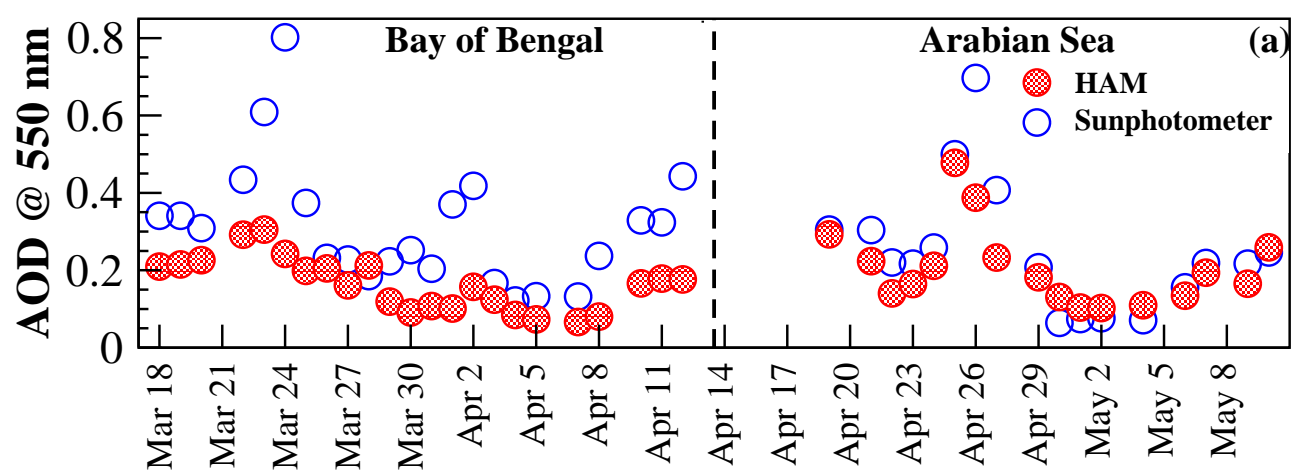

DAYS

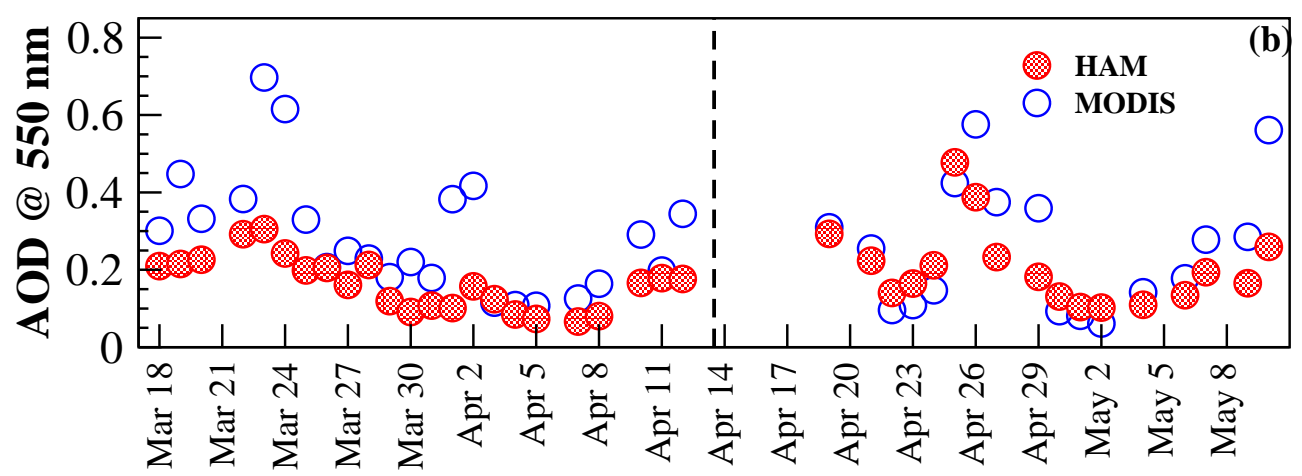

DAYS

Fig. 1. Comparison of model derived aerosol optical depth (AOD) at $550 \mathrm{~nm}$ with (a) ship-based remote sensing measurements and (b) MODIS satellite retrievals during the ICARB cruise period from 18 March to 10 May 2006.

Table 1. Comparison between the ship-based remote sensing measurements, MODIS observations and model-simulated mean AODs over the Bay of Bengal and Arabian Sea legs during ICARB cruise period.

\begin{tabular}{lccl}
\hline & \multicolumn{2}{c}{ Mean Aerosol Optical } \\
Depth (AOD) @ 550 nm & References \\
\hline & $\begin{array}{c}\text { Bay of } \\
\text { Bengal (\# 23) }\end{array}$ & $\begin{array}{c}\text { Arabian } \\
\text { Sea (\# 17) }\end{array}$ \\
\hline HAM & 0.19 & 0.21 & Present study \\
Sunphotometer & 0.31 & 0.25 & Kedia and \\
MODIS & 0.29 & 0.26 & Pamachandran (2008) \\
\hline
\end{tabular}

greater than 20 are treated as cloud-free days. Seven days (25 March, 30 March, 2 April, 12 April, 21 April, 7 May and 10 May) were identified as cloud contaminated days since they show less than 20 valid MODIS AOD retrievals. The model-simulated AOD agrees better with ship-based observations on cloud-free days compared to all days during the ICARB cruise period in terms of error (Root mean square error, RMSE of 0.13 vs. 0.16 ; Table 3 ) and in terms of variability ( $R=0.78$ vs. 0.69 ). However, the modelled AOD un- derestimates the AOD derived from MODIS data relatively higher during cloudy days compared to cloud-free days (2 vs. 1.44). The ratio of modelled AOD to MODIS AOD amounts to 0.5 and 0.69 for cloudy days and cloud-free days, respectively (Table S1). The Ångström Exponent (AE) is relatively well simulated by the model (slightly higher compared to MODIS, on average by $5 \%$; see Table S1) on clear days compared to MODIS derived AE values. However, model-simulated $\mathrm{AE}$ overestimates the $\mathrm{AE}$ derived from MODIS data by a factor of 1.28 (0.78 vs. 0.61) during cloudy days (Table S1). This indicates that particles are too small in the model on cloudy days, leading to the conclusion that the simulated swelling of aerosol particles through water uptake near cloudy areas is deficient, consistent with the low-bias in model-simulated AOD compared to MODIS observations during cloudy days $(15 \%)$. The fact that the ECHAM5.5-HAM model and MODIS AOD compare better in cloud-free situations corroborated this conclusion. Similar conclusions were found for the comparison between MODIS data and the sunphotometer, as well as when comparing the simulation to MODIS satellite retrievals. This indicates that swelling due to high relative humidity in cloudy situations and/or cloud contamination introduces additional variability, so that the single-column ship-based observations represent the large-scale MODIS retrievals only to a lesser extent. 
Table 2. Linear regression statistics between the ship-based remote sensing measurements, MODIS observations and model-simulated AODs over the Bay of Bengal and Arabian Sea legs during ICARB cruise period.

\begin{tabular}{|c|c|c|c|c|c|c|}
\hline \multirow[b]{2}{*}{ Region } & \multirow[b]{2}{*}{ Statistics } & \multirow{2}{*}{$\begin{array}{r}\text { Sunphotometer } \\
\text { vs. MODIS }\end{array}$} & \multirow{2}{*}{$\begin{array}{r}\text { Sunphotometer } \\
\text { vs. HAM }\end{array}$} & \multicolumn{3}{|c|}{ MODIS vs. HAM } \\
\hline & & & & Total & Fine & Coarse \\
\hline \multicolumn{2}{|c|}{ Number of observations } & 40 & 40 & 40 & 40 & 40 \\
\hline \multirow{4}{*}{ Total } & Correlation coefficient $(R)$ & 0.85 & 0.69 & 0.70 & 0.62 & 0.42 \\
\hline & Slope & $0.82 \pm 0.08$ & $0.36 \pm 0.06$ & $0.38 \pm 0.06$ & $0.37 \pm 0.08$ & $0.17 \pm 0.06$ \\
\hline & Root mean square error (RMSE) & 0.09 & 0.16 & 0.15 & 0.09 & 0.09 \\
\hline & Mean bias (MB) & $-0.01^{1}$ & $-0.10^{1}$ & $-0.09^{2}$ & $-0.04^{2}$ & $-0.05^{2}$ \\
\hline \multirow{4}{*}{ Bay of Bengal } & Correlation coefficient $(R)$ & 0.92 & 0.68 & 0.75 & 0.65 & 0.24 \\
\hline & Slope & $0.89 \pm 0.08$ & $0.29 \pm 0.07$ & $0.33 \pm 0.06$ & $0.29 \pm 0.07$ & $0.09 \pm 0.08$ \\
\hline & Root mean square error (RMSE) & 0.07 & 0.19 & 0.17 & 0.11 & 0.09 \\
\hline & Mean bias (MB) & $-0.03^{1}$ & $-0.13^{1}$ & $-0.10^{2}$ & $-0.07^{2}$ & $-0.05^{2}$ \\
\hline \multirow{4}{*}{ Arabian Sea } & Correlation coefficient $(R)$ & 0.77 & 0.88 & 0.77 & 0.79 & 0.58 \\
\hline & Slope & $0.76 \pm 0.16$ & $0.55 \pm 0.08$ & $0.49 \pm 0.1$ & $0.68 \pm 0.14$ & $0.22 \pm 0.08$ \\
\hline & Root mean square error (RMSE) & 0.11 & 0.10 & 0.11 & 0.05 & 0.09 \\
\hline & Mean bias (MB) & $0.01^{1}$ & $-0.04^{1}$ & $-0.05^{2}$ & $-0.01^{2}$ & $-0.05^{2}$ \\
\hline
\end{tabular}

${ }^{1}$ Mean bias is calculated relative to sunphotometer values. ${ }^{2}$ Mean bias is calculated relative to MODIS values.

Table 3. Linear regression statistics between the ship-based remote sensing measurements, MODIS observations and model-simulated AODs during Bay of Bengal and Arabian Sea cruise period.

\begin{tabular}{|c|c|c|c|c|c|c|}
\hline \multirow[b]{2}{*}{ Statistics } & \multicolumn{2}{|c|}{$\begin{array}{l}\text { Sunphotometer } \\
\text { vs. MODIS }\end{array}$} & \multicolumn{2}{|c|}{$\begin{array}{l}\text { Sunphotometer } \\
\text { vs. HAM }\end{array}$} & \multicolumn{2}{|c|}{$\begin{array}{c}\text { MODIS } \\
\text { vs. HAM }\end{array}$} \\
\hline & All days & Cloud free days & All days & Cloud free days & All days & Cloud free days \\
\hline Correlation coefficient $(R)$ & 0.85 & 0.92 & 0.69 & 0.78 & 0.70 & 0.72 \\
\hline Slope & $0.82 \pm 0.08$ & $0.92 \pm 0.07$ & $0.36 \pm 0.06$ & $0.48 \pm 0.07$ & $0.38 \pm 0.06$ & $0.44 \pm 0.06$ \\
\hline RMSE & 0.09 & 0.06 & 0.16 & 0.13 & 0.15 & 0.13 \\
\hline BIAS & -0.01 & -0.02 & -0.10 & -0.09 & -0.09 & -0.07 \\
\hline
\end{tabular}

In summary, the inconsistency between model and remote sensing estimates mainly arises from the uncertainties associated with satellite retrievals (e.g. uncertainties with cloud contamination or surface albedo) and from the inaccuracies in the model representation of aerosol and cloud processes. Other reasons are associated with relative humidity ( $\mathrm{RH})$. In this regard, though, a recent comparison of aerosol swelling in terms of the statistical relationship between cloud cover and AOD found a good global agreement between ECHAM5.5-HAM and MODIS satellite retrievals (Quaas et al., 2010). In the model, aerosol water uptake is treated by using a single humidity value rather than a distribution (Quaas et al., 2010). This treatment may nonlinearly increase the water uptake in regions where $\mathrm{RH}$ is greater than $80 \%$ (e.g. near cloud edges or oceans), as reported in previous studies (e.g. Haywood et al., 1997; Bian et al., 2009). This would likely underestimate the real effect of water uptake over these regions.
The impact of the temporal vs. geographical evolution on the AOD values along the ship track was investigated to judge whether the AOD variability for the oceanic regions and season as observed during ICARB was representative of the entire region and season. This analysis was carried out using the two observational data sets (ship-based sunphotometer single-column measurements and MODIS satellite large-scale observations). Table 4 shows two ways of correlating ship-based sunphotometer data to large-scale MODIS retrievals: (i) sampling the MODIS data along the ship track - this was sampling the full spatio-temporal variability available from ICARB; and (ii) sampling MODIS data along the track, but from the seasonal mean AOD distribution - this was sampling only the geographical variability along the track. As expected, the spatial-only, seasonal-mean sampling from MODIS does not agree as well to the sunphotometer data in any of the statistical measures - particularly the large slope of the regression gets much worse. Still, we found that a large part of the variability was explained by the 
geographical variability, and the temporal variability (that is, specific pollution events) contribute only to a minor extent to the overall variability along the ICARB track (correlation coefficient $R=0.71$ for the seasonal-mean sampling vs. 0.85 for the full spatio-temporal sampling along the track). Splitting this up, we found that in the $\mathrm{BoB}$, individual events were more important than in the AS region, where even the correlation coefficient was slightly larger for seasonal-mean sampling (a result probably just showing a statistical uncertainty in the correlation coefficient).

In this study, the climatology of aerosol properties from remote sensing estimates is used to examine how representative are the simulated aerosol properties for the multiyear period during the pre-monsoon season over $\mathrm{BoB}$ and $\mathrm{AS}$ regions. For this, a $6 \mathrm{yr}$ (2001-2006) MODIS mean and the reported 9 yr (2000-2008) Multiangle Imaging spectroradiometer (MISR) values (Dey and Di Girolamo, 2010) are used. Similar seasonal-mean AOD values $(0.33 \pm 0.05)$ were reported from MISR climatology (Dey and Di Girolamo, 2010) and MODIS climatology $(0.29 \pm 0.02)$ during pre-monsoon season over both $\mathrm{BoB}$ and AS regions (Table S2). Model simulations also show similar AOD values $(0.27 \pm 0.06)$ over $\mathrm{BoB}$ and $\mathrm{AS}(0.26 \pm 0.09)$ regions during the pre-monsoon season (March-May) of 2006, which is slightly less in magnitude compared to MISR and MODIS multi-year mean AOD values. Similarly, the modelsimulated AE values also capture the reported MISR climatology values over both $\mathrm{BoB}$ and AS regions (Table S2). Agreement between simulated aerosol properties with MISR and MODIS climatology (slightly less in AOD magnitude) implying that the AOD and AE simulated by the model well represent the pre-monsoon climatology of aerosol properties over $\mathrm{BoB}$ and $\mathrm{AS}$ regions.

For evaluating the spatial distribution of model-simulated aerosol optical properties, the mean (averaged from 18 March to 10 May) of the model derived AOD at $550 \mathrm{~nm}$ was compared to mean MODIS satellite observations (Fig. 2). Both simulated and satellite-retrieved AODs were found to be high close to the coast and near populated urban locations. Over the BoB, a clear gradient was seen, with AOD decreasing from north-west to south-east (Fig. 2) and the high AOD values were mainly attributed to continental outflow from the Indo-Gangetic Plain (IGP) and east Asia, as well as long-range transport of mineral dust aerosols from the west Asian regions. This gradient was captured well by the model, which, however, shows an overall underestimation quantitatively. The high values of simulated AODs along the Mangalore coast appear to be a consistent feature over the AS region along with ICARB observations (Moorthy et al., 2008), and were reported during several earlier cruise studies (Parameswaran et al., 1999; Moorthy and Saha, 2000; Ramachandran, 2004), which was also captured in satellite observations (Fig. 2). However, the simulated plume does not extend far enough to the North, but, on the other hand, extends too far off shore. The analysis of simulated spatial distributions of individual aerosol species showed that sulfate plumes extending from south-east India to the AS and dust plumes extending from west Asia and western India to the AS resulted in high AODs near the Mangalore coast during ICARB period. Receptor modelling analysis also showed that this period was associated with an increased outflow from west Asia and western coast of India (Cherian et al., 2010), more subject to dust emissions. The spatial distribution of simulated AOD agrees well $(R=0.8$, see Table 2$)$ with MODIS observations in most of the AS regions. Over the $\mathrm{BoB}$ region, it was systematically underestimated by a factor of 1.5, specifically near coastal regions (Fig. 2), but variability still was relatively well captured $(R=0.75)$.

The spatial representativeness of model-simulated AOD during the pre-monsoon 2006 was examined using the multi-year (2001 to 2006) MODIS derived AOD distributions. The normalized anomaly of model-simulated 2006 pre-monsoon mean AOD [(MEAN_MODEL 2006 MEAN_MODIS $2001-2006$ )/STDEV_MODIS $2001-2006$ ] from the multi-year pre-monsoon mean MODIS AOD (2001 to 2006) was used to examine the regional representativeness of model-simulated AOD during ICARB period (Fig. 3). Negative $(-0.5$ to -1$)$ anomalies were found over BoB region. This indicates a significant underestimation of AOD in the model compared to satellite retrievals during this period, whereas less positive/negative phase $(-0.25$ to +0.25$)$ anomalies were found in the Arabian Sea region (Fig. 3c). The deviations of the year 2006 AOD distribution as retrieved by MODIS from the multi-year mean value are insignificant in most of the BoB and AS regions (Fig. 3d). This suggests a very low interannual variations occurred in both these locations in the time period analysed. It also proves that the year 2006 in which the ICARB campaign took place was representative for typical aerosol distributions during premonsoon seasons in the early to mid 2000s. For understanding the model discrepancies in aerosol representation, the simulated AOD was examined for the different modes which are discussed in the following sections.

\subsection{Fine and coarse mode AOD}

To understand the model underprediction in more detail, the modelled AODs at $550 \mathrm{~nm}$ were compared with satellite observations (MODIS, Terra \& Aqua combined) in fine and coarse modes (see Fig. 4). MODIS fine and coarse mode AOD was derived using the MODIS AOD and fine mode fraction (FMF) values. HAM fine mode AOD was estimated by adding the Aitken and accumulation mode (both soluble and insoluble modes) AODs. Both simulated fine and coarse mode AODs agree rather well ( $R=0.79$ and $R=0.58$, Table 2) with MODIS fine and coarse mode AODs over the AS legs in terms of variability, but showed a certain underestimation quantitatively, especially for a few days, where in particular the coarse mode was substantially underestimated (Fig. 4). During the BoB leg, most of the fine mode 
Table 4. Comparison of linear regression statistics between the ship-based remote sensing measured and MODIS retrieved AODs for the temporal (sampled at the right days along the track) and seasonal mean (ICARB period mean geographical distribution sampled along the ship track) during ICARB cruise period.

\begin{tabular}{|c|c|c|c|c|c|c|}
\hline \multirow{2}{*}{ Sunphotometer vs. MODIS } & \multicolumn{2}{|c|}{ Total } & \multicolumn{2}{|c|}{ Bay of Bengal } & \multicolumn{2}{|c|}{ Arabian Sea } \\
\hline & Temporal & Seasonal mean & Temporal & Seasonal mean & Temporal & Seasonal mean \\
\hline Correlation coefficient $(R)$ & 0.85 & 0.71 & 0.92 & 0.61 & 0.77 & 0.80 \\
\hline Slope & $0.82 \pm 0.08$ & $0.34 \pm 0.05$ & $0.89 \pm 0.08$ & $0.25 \pm 0.07$ & $0.76 \pm 0.16$ & $0.43 \pm 0.08$ \\
\hline RMSE & 0.09 & 0.12 & 0.07 & 0.13 & 0.11 & 0.11 \\
\hline BIAS & -0.01 & -0.03 & -0.03 & -0.04 & 0.01 & -0.02 \\
\hline
\end{tabular}
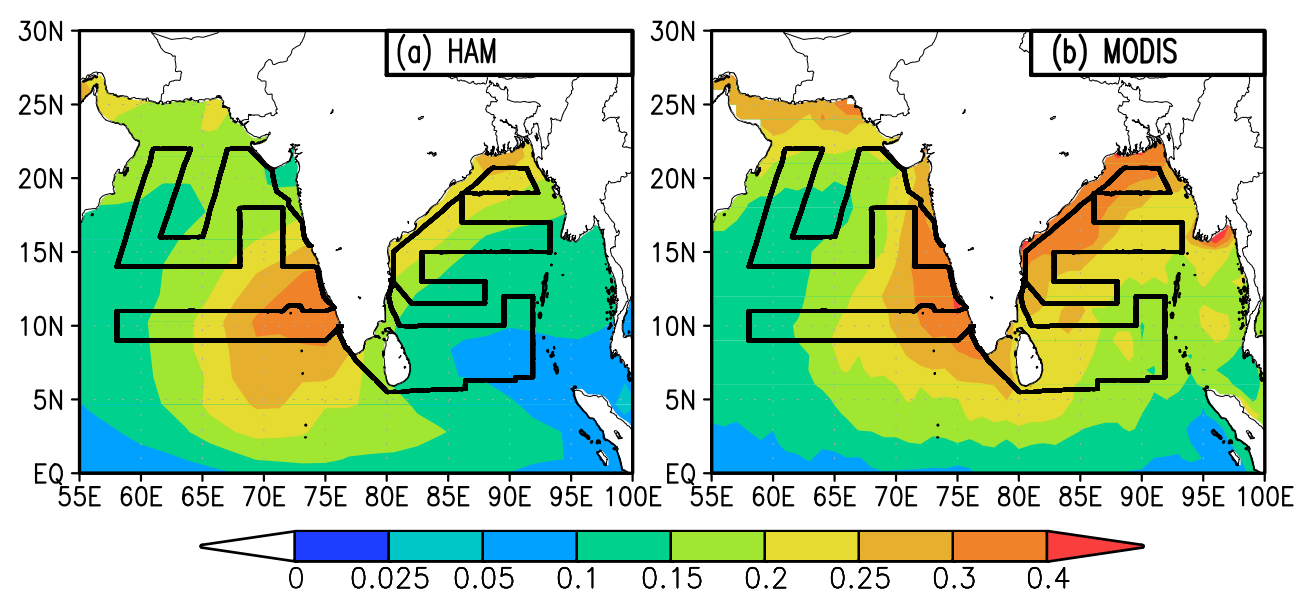

Fig. 2. AOD distributions at $550 \mathrm{~nm}$ wavelength (a) as simulated by ECHAM5.5-HAM and (b) as retrieved by the MODIS satellite sensors (Terra and Aqua combined), averaged over the ICARB cruise period.

AODs were underpredicted by up to a factor of 2 to 3 , while coarse mode AODs were occasionally significantly underpredicted by a factor of 3 to 6 with a regression slope as low as 0.09 (Table 2). The reasons for the underestimation of both fine and coarse AODs are discussed later. The variability in the fine mode was acceptably well simulated also for the BoB leg $(R=0.65)$, but severely wrong for the coarse mode $(R=0.24)$.

The significant underestimation of fine and, particularly, coarse mode AODs during BoB leg may result from incorrect aerosol emissions, or aerosol transport. To examine this further, the chemical composition for fine and coarse mode column burden was analysed (see Fig. S1). It was found that the anthropogenic aerosols (sulfate and, to a lesser extent, organic carbon), dominate (50-80\%) the fine mode column burden, with the remaining parts mostly from aerosol water uptake, and negligible contributions from dust, black carbon and sea salt. Natural aerosols (dust and, to a much lesser extent, sea salt) were dominant $(90 \%)$ to the coarse mode column burden during these periods (see Fig. S1). Especially over the AS leg, water was found to be a large contributor to the coarse-mode column burden as well. Back trajectory and receptor model analysis showed that air mass during this period was associated with an outflow from the Indo-Gangetic plain or central India (anthropogenic aerosols) and the western India or Arabia (dust emissions) (Cherian et al., 2010). However, the impact of the continental advection decreased continuously as the ship moved southwards. In the model, the emission of mineral dust depends on the online prognostic wind speed at $10 \mathrm{~m}$ above the surface and the prescribed surface feature of soils (Stier et al., 2005). Some of the observed coarse mode AOD may stem from dust emissions, which were not well represented, or not included at all, in the model. This may also contribute to the underestimation of coarse mode AODs during the BoB legs. Deficiencies in the simulation of aerosol transport and processing may also contribute. The limited number of in-situ observations might reduce the quality of ECMWF reanalysis data over the Indian Ocean region (Bonazzola et al., 2001), potentially biasing the wind fields used for nudging in the ECHAM5.5HAM simulations. This reduces the fidelity of the transport of continental anthropogenic aerosols to the BoB regions, thus contributing to the underestimation of the fine AODs over these regions.

Huneeus et al. (2011), using multiple model intercomparison study, suggested that the underestimation of AOD and overestimation of AE indicate whether a model is underestimating dust emissions in particular regions. In this 

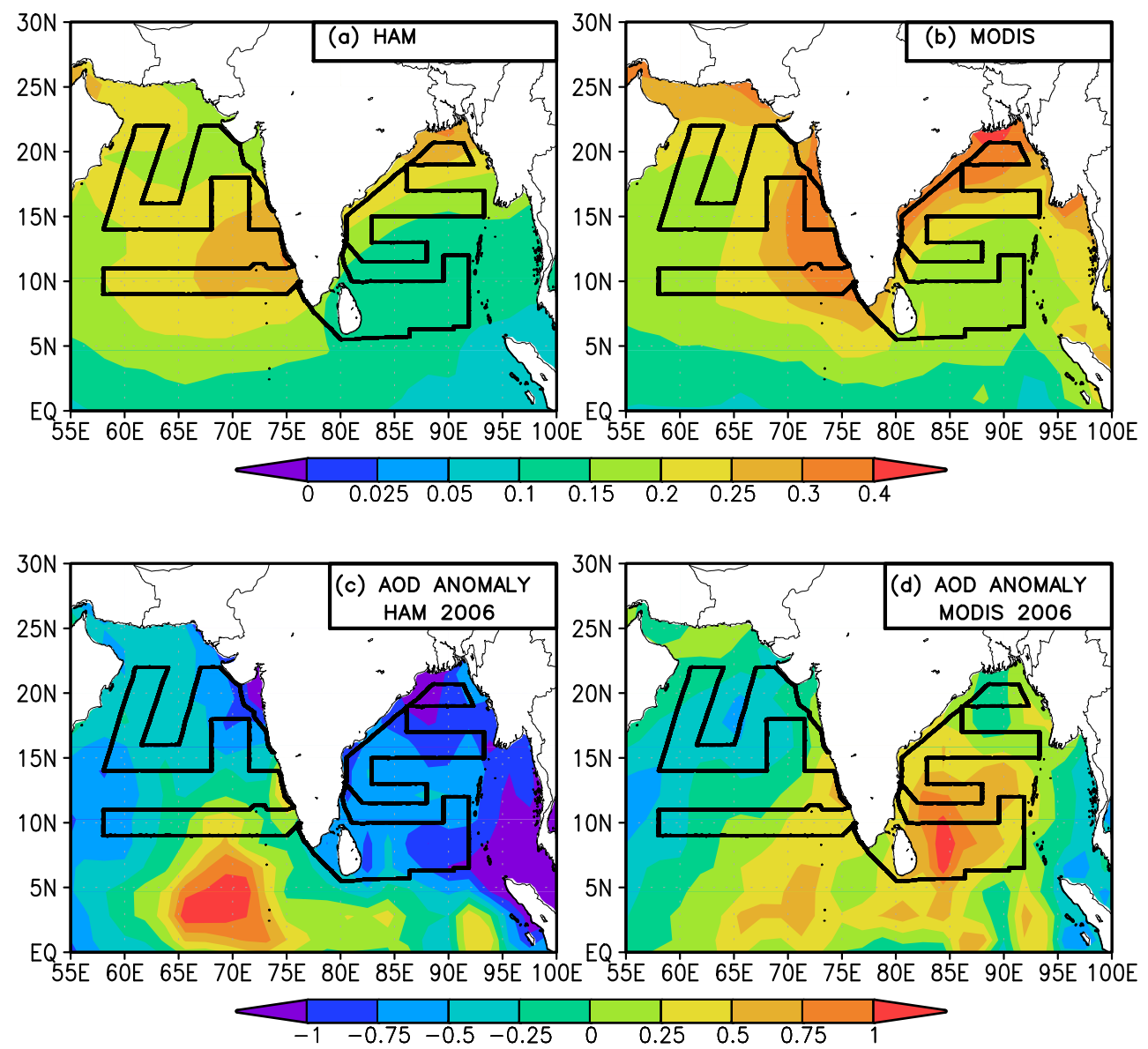

Fig. 3. AOD distributions at $550 \mathrm{~nm}$ wavelength (a) as simulated by ECHAM5.5-HAM and (b) as retrieved by the MODIS satellite sensors (Terra and Aqua combined), averaged for $6 \mathrm{yr}$ (2001 to 2006) during 18 March to 10 May. Normalized anomaly of (c) model-simulated

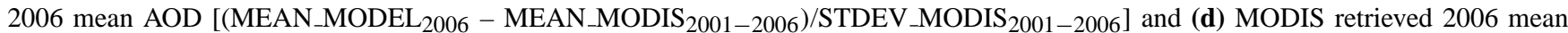
AOD [(MEAN_MODIS 2006 - MEAN_MODIS $\left.2001-2006) / S T D E V \_M O D I S_{2001-2006}\right]$ from the 6 yr averaged satellite retrieved AOD during 18 March to 10 May.

study, the model-simulated AOD is underestimated by a factor of 3 during 24 March, 1, 2, 8 and 12 April days over the BoB leg (Table 5). On the other hand, the model-simulated $\mathrm{AE}$ is overestimated, compared to the sunphotometer-based $\mathrm{AE}$ during these days. The simultaneous underestimation of the AOD and overestimation of the AE points to an underestimation of the coarse dust emissions if a too small contribution from other coarse mode aerosol components can be excluded (Huneeus et al., 2011).

Model inter-comparison studies showed that the simulated lifetime of dust aerosols is 4.6 days on average (Huneeus et al., 2011). We performed a five day air mass back trajectory analysis (from starting altitudes of $100 \mathrm{~m}, 500 \mathrm{~m}$, $1000 \mathrm{~m}$ and $2500 \mathrm{~m}$ ), which shows an air mass outflow from western Indian regions during these days (see Fig. S2) that is consistent with previous analysis (Kedia et al., 2010). This analysis shows that 4 to 5 days are needed for dust aerosols to reach the observation point. To examine dust
AOD underestimation further, the simulated dust AOD was compared with the satellite derived UV AI during 18 March, 19 March, 28 March, and 2 April periods (Fig. 5). It was found that the missing of Thar Desert dust plumes during these days resulted in very low AODs during 24 March, 1, 2, and 8 April days over the BoB leg (Fig. 1). A too small dust emission flux over the Thar Desert was found on 18 and 19 of March 2006 that lead to AOD underestimation on 24 March in model-simulated aerosol fields. At the same time, UV AI values over the Thar Desert region confirm the existence of significant dust outbreak events (Fig. 5). The $\mathrm{AI}$ indeed exceeds a value of 1.0 in the region of the Thar Desert, signifying the existence of aerosols absorbing UV radiation. Such approaches were previously used to identify missing dust source episodes (Flaounas et al., 2009). Similarly, the underestimated dust source over the Thar Desert during 28 and 29 March lead to too low AODs during 1 and 2 April. However, low AOD on 12 April mainly stems from 


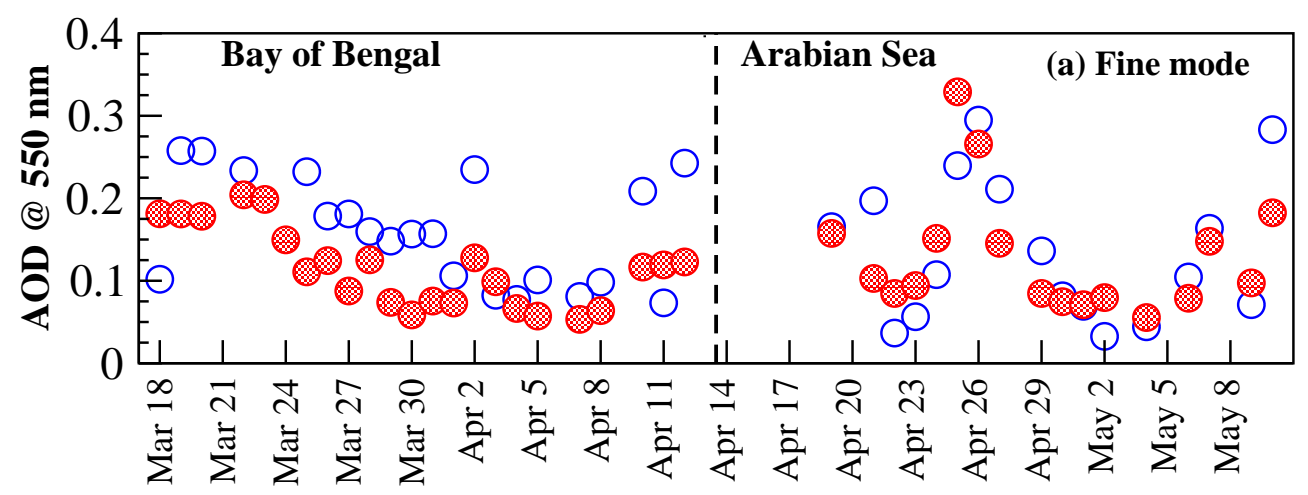

DAYS

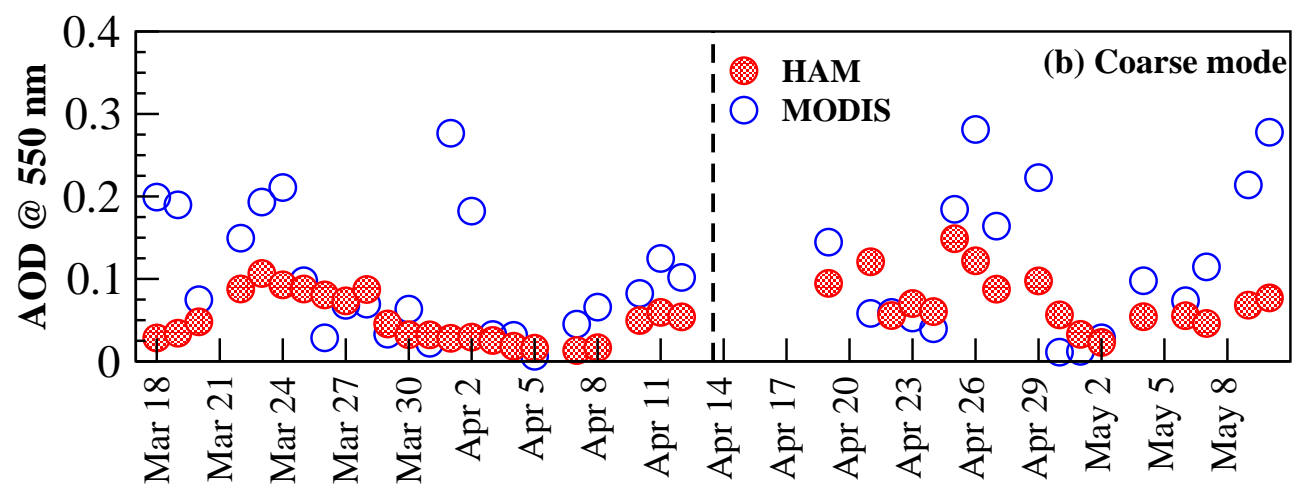

DAYS

Fig. 4. Comparison of modelled fine (a: upper panel) and coarse mode (b: lower panel) AODs at $550 \mathrm{~nm}$ against satellite observations during the ICARB 2006 cruise period.

Table 5. Comparison of modelled AOD and Ångström Exponent (AE) with sunphotometer measured during missing dust source days and entire BoB leg.

\begin{tabular}{cccccc}
\hline & \multicolumn{2}{c}{ AOD @ 550 nm } & & \multicolumn{2}{c}{ Ångström Exponent (AE) } \\
\cline { 2 - 2 } $\begin{array}{c}\text { Sunphotometer } \\
\begin{array}{c}\text { (24 March, 1 2, 8, } \\
\text { and 12 April) }\end{array}\end{array}$ & 0.45 & 0.15 & & 1.16 & 1.28 \\
\hline BoB mean & 0.31 & 0.19 & & 1.12 & 1.11 \\
\hline
\end{tabular}

the missing dust source regions from west Asian regions (Fig. S2). The fact that the model compares better in average situations compared to missing-dust source days points to the inaccuracies in simulating enough dust emission flux during these days. Even if in general, the model-simulated dust AOD in the same locations where the UV Aerosol Index (AI) indicates dust source regions (Arabian peninsula, Thar Desert), relatively little dust was transported to the ship location from the northern Indian subcontinent. This anomalous transport results in rather low coarse mode AOD in most of the BoB cruise days (Fig. 5).
Finally, there might be a mis-representation of aerosol wet scavenging and sedimentation. To examine this further, the wet and dry deposition flux of dust aerosols were analysed during the entire BoB cruise period and separately for the days where the model failed to capture large values of coarsemode AODs. It was found that the fraction of dust removed from the atmosphere by both dry and wet deposition is comparable during the days where the model lacks dust and the average over the BoB period (Fig. S3). Also the aging of dust result from microphysical processing is not very different in the four days with the low-bias in dust. However, a 

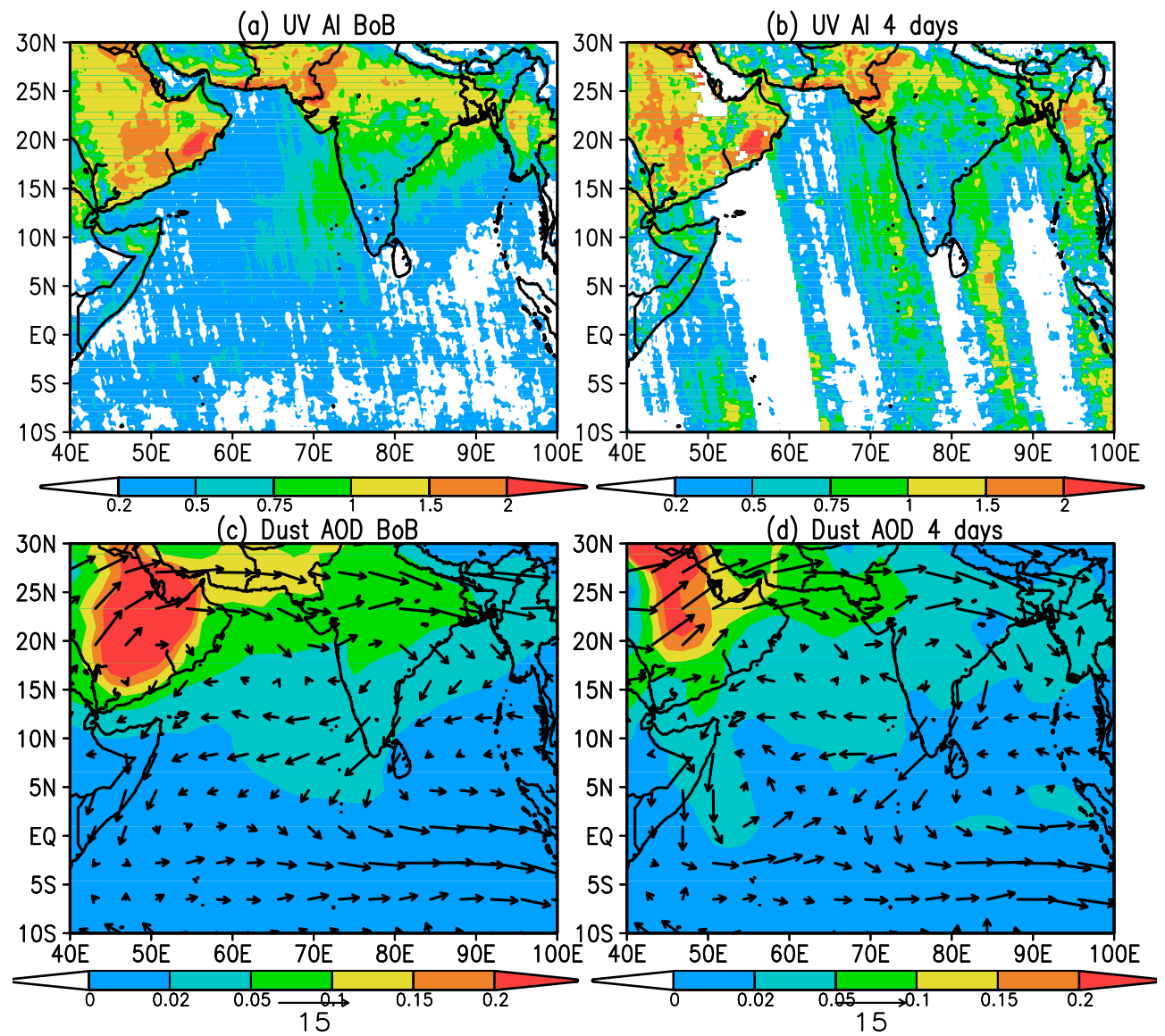

Fig. 5. Comparison of modelled dust AOD at $550 \mathrm{~nm}$ to Aura-OMI satellite derived UV Aerosol Index (AI) for the entire BoB periods (18 March-11 April; a and c) and for the average of 4 days when dust from source regions was missing in ECHAM5.5-HAM (18 March, 19 March, 28 March, and 2 April, b and d).

particularly low model dust emission flux was found during these 4 days (18 March, 19 March, 28 March, and 2 April) over the Thar Desert (north-west India) region (Fig. S4).

The primary factors governing the magnitude and geographical location of dust emissions are the soil erodibility factor and wetness of the surface (soil moisture) treatment in dust parameterisations. In the current dust emission scheme of ECHAM5.5-HAM, global soil textures were prescribed for preferential source regions (Tegen et al., 2002), which results in a significant underestimate of the dust emission flux over Asian regions (Cheng et al., 2008). Alternate approaches, e.g. reflectivity-based soil erodibility factor (Grini et al., 2005), which show better agreement of dust flux with measurements, might improve dust parameterization in ECHAM5.5-HAM. Over arid regions, dust flux is sensitive to wetness of the surface (soil moisture), which is influenced by the amount of regional rainfall. The time required by the soil to dry after a small rainfall depends on air temperature, humidity, surface winds, and soil texture. Currently prescribed soil textures (Tegen et al., 2002) would not accurately reflect these processes. Other approaches, e.g. the parameterization of the soil moisture effect into the ECHAM5.5-HAM dust emission scheme (Cheng et al., 2008), which show improved dust emission in east Asia, might improve the dust emission flux over Thar Desert region. Wind speed is another key variable that influences desert dust lifting and transport. The model-simulated surface wind speed over the Thar Desert is found to be similar during missing dust source days compared to normal days suggesting little evidence of anomalously low wind speed influencing suppressed dust activity (Fig. 4). Other approaches (Grini et al., 2005), which represent sub grid wind speed variability as a probability distribution function (PDF), predict dust better over dust sourceregions, but show anomalous increases in dust emissions in non-desert regions at low mean wind speeds (Grini et al., 2005). In the current scheme super-coarse mode dust particles are neglected in the emission calculation based on the assumption that they settle down very quickly because of large masses. This assumption also possibly contributes to the underestimation of dust emission when gusty wind prevails over these regions (Cheng et al., 2008). 
In summary, the underestimation of AOD (mainly coarse AOD) in high AOD periods mainly stem from missing aerosol sources (most probably was coarse mode dust mainly in Thar Desert areas - but also fine mode sulfate and OC). Though ECHAM5.5-HAM AOD estimates were underestimated in high pollution episodes (especially over the $\mathrm{BoB}$ regions), the model still is a valuable tool to understand the mean pre-monsoon aerosol size distribution, atmospheric absorption, and radiative effects during the ICARB period.

\section{3 Ångström Exponent}

The spatial distribution of the simulated Ångström Exponent (AE, $\alpha, 550 \mathrm{~nm} / 825 \mathrm{~nm})$ was evaluated using the satellite retrieved AE from the MODIS sensor $(550 \mathrm{~nm} / 865 \mathrm{~nm}$, Terra and Aqua combined) during the ICARB cruise period (Fig. S5). Some features of the geographical distribution of the simulated $\alpha$ agrees well with satellite observations over the AS regions. Low $\alpha$ value (large particle sizes) were simulated in the northern AS region, in close agreement with the satellite retrievals. Also the pattern of the north-east to southwest decreasing gradient of $\alpha$ (increasing particle sizes) moving away from the coast was well represented. However, the model consistently overestimates $\alpha$, or underestimates aerosol particle size, consistent with the above finding of too little simulated dust concentrations. Over the BoB, the model showed far too little variability, and - as for the AS region particle sizes were underestimated. The overall gradient of decreasing particle sizes moving away from the Indian coast, though, was simulated. High values of $\alpha$ (1-1.5) were found over the BoB leg indicating a relatively large fraction of fine mode particles (Fig. S2), while large heterogeneities found over AS leg with relatively small values $(<1)$ of $\alpha$ (Fig. S2). The southern AS (south of $14^{\circ} \mathrm{N}$ ) was characterized by high values of $\alpha$ with values in the range 0.6 to 0.8 ( 0.85 to 1 in the model), indicating high relative abundance of accumulation mode (sulfate) aerosols (Fig. S5). Compared to this, the northern AS (north of $15^{\circ} \mathrm{N}$ ) was dominated by coarser mode aerosols (dust) and $\alpha$ value in the range 0.45 to 0.75 , consistent in both model and satellite retrievals (Fig. S5). The coarse mode aerosols were mainly associated with mineral dust (see previous section and Fig. S1). The percentage contribution of fine mode (accumulation + Aitken) particles to total AODs was found to be high $(68 \%)$ - this also shows the dominance of fine mode aerosols (sulfate and OC aerosols in accumulation soluble mode) over the BoB legs in the model, indicating the transport from IGP and central India regions (see Table S3). This was consistent with findings based on measurements (Kedia and Ramachandran, 2008), which showed larger AODs and FMFs, and receptor modeling (Cherian et al., 2010), which showed the predominance of anthropogenic factors, during the cruise over the $\mathrm{BoB}$ when the ship was mainly influenced by air masses from the IGP or central India.

\subsection{Aerosol absorption and radiative forcing}

Aerosol absorption determines the amount of solar heating by atmospheric aerosol and may be quantified by the aerosol absorption optical depth (AAOD), which is defined as the product of the AOD and aerosol single scattering co-albedo. For evaluating the spatial distribution of aerosol absorption, the mean (averaged over the 18 March to 10 May period) simulated AAOD at $550 \mathrm{~nm}$ was compared to OMI (aboard EOS-Aura) retrieved AAOD at $500 \mathrm{~nm}$ (Fig. 6). High AAOD values were found over the biomass regions of India and east Asia regions (Fig. 6). Good agreement for the geographical distribution of absorption was found for large AOD regions over land between OMI and simulated AAOD values, while OMI AAOD was found to be very low over most of the oceanic regions (Fig. 6). However, OMI retrievals carry a significant uncertainty with likely underestimation of AAOD at low AOD values as those observed over the ocean. The uncertainty in satellite retrieval was mainly associated with the assumed aerosol layer height, aerosol type misidentification ( 3 basic types such as dust, carbonaceous aerosols and weakly absorbing sulfates) and cloud contamination (Torres et al., 2007). The model showed that absorption of solar radiation by aerosols was mostly result from BC (about $80 \%$ to $90 \%$ ) over the oceans and continent regions, with remaining portion accounted for by mineral dust and OC (see Fig. 6c-d).

A summary of SSA measurements carried out in the recent years over $\mathrm{BoB}$ and $\mathrm{AS}$ regions is given in Table 6 along with model-simulated SSA values. The mean value of modelsimulated SSA value over BoB is found to be $0.91 \pm 0.02$, which is consistent with the finding from ICARB measurements (Nair et al., 2008; Kedia et al., 2010) and from previous INDOEX measurements (Ramanathan et al., 2001). The mean SSA $(0.94 \pm 0.01)$ value (see Table 6) over AS is also found to be within the range of uncertainties of the measured SSA values (Kedia et al., 2010). The mean SSA value over $\mathrm{AS}$ is higher than $\mathrm{BoB}$ region indicate that the dominance of absorbing (BC) aerosols over $\mathrm{BoB}$ regions. SSA values from previous studies (Ramanathan et al., 2001; Ramachandran and Jayaraman, 2002) were found to be slightly lower over BoB and AS regions (Table 6) because all these studies were conducted in the winter monsoon season (DecemberMarch) during which the absorbing aerosols from the south Asian region get transported to these regions. The close correspondence between the model-simulated and the measured (Nair et al., 2008; Kedia et al., 2010) SSA value indicate that representation of chemical composition and mixing state in the model is likely to be valid over BoB and AS regions.

The model-simulated short-wave (SW) clear-sky direct aerosol radiative forcing (DARF) at the TOA $\left(\Delta F_{\mathrm{TOA}}\right)$, surface $\left(\Delta F_{\mathrm{SUR}}\right)$ and, within the atmosphere $\left(\Delta F_{\mathrm{ATM}}=\right.$ $\left.\Delta F_{\mathrm{TOA}}-\Delta F_{\mathrm{SUR}}\right)$ was analysed to determine the aerosol direct radiative effects during ICARB period. The simulated mean DARF sampled along the ship track over BoB leg was 

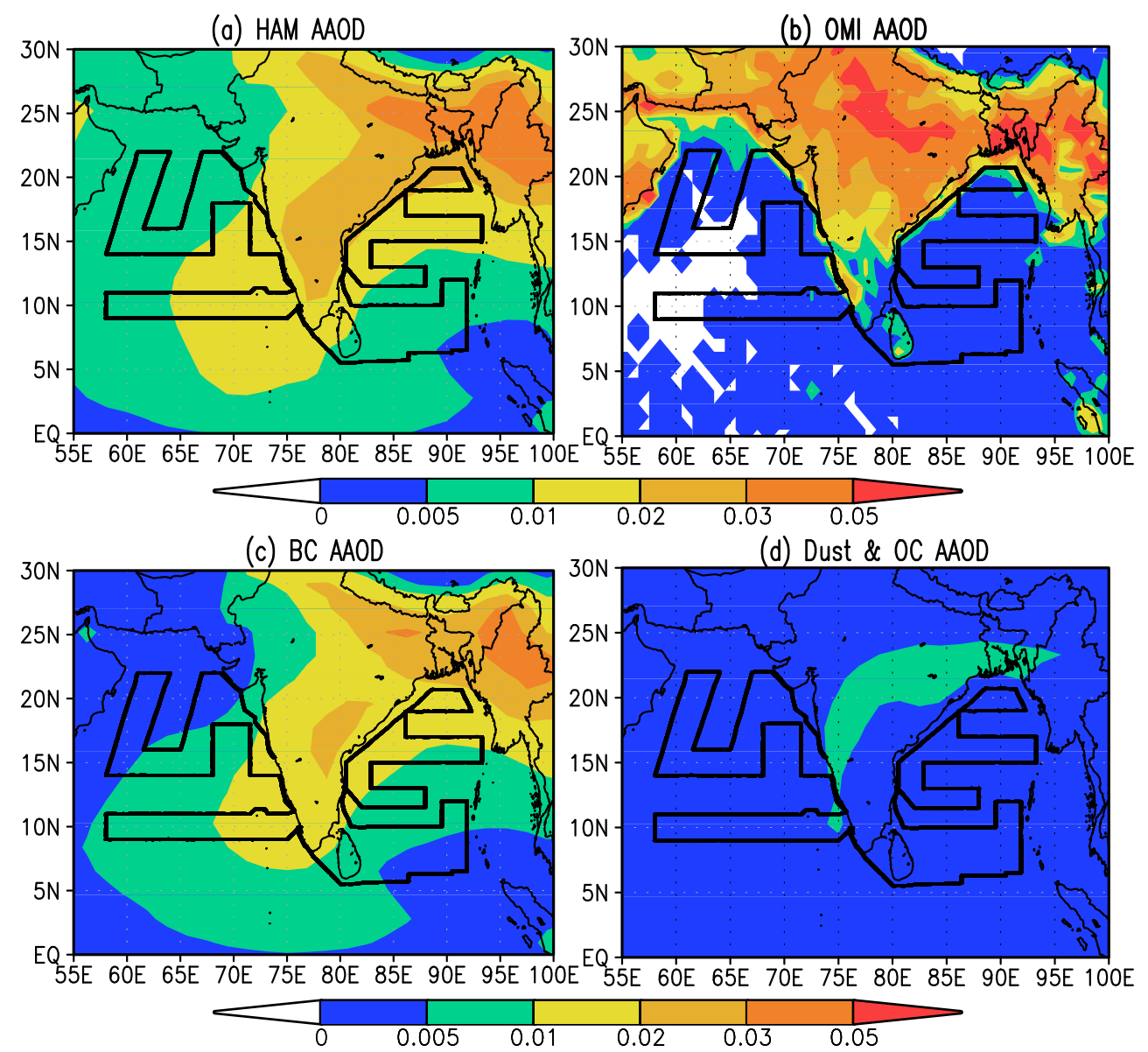

Fig. 6. Comparison of (a) modelled absorption optical depth (AAOD) at $550 \mathrm{~nm}$ and (b) Aura-OMI satellite derived AAOD at $500 \mathrm{~nm}$ averaged over the ICARB 2006 period. The simulated contributions of (c) BC and (d) Dust plus OC, to total AAOD, respectively, are also shown.

Table 6. Mean single scattering albedo (SSA) over the Bay of Bengal and Arabian Sea region obtained from present study in comparison with earlier studies.

\begin{tabular}{lrc}
\hline Region and source & Period & SSA \\
\hline Bay of Bengal & & \\
\hline Present study & March-April 2006 & $0.91 \pm 0.02$ \\
Nair et al. (2008) & March-April 2006 & $0.93 \pm 0.02$ \\
Kedia et al. (2010) & March-April 2006 & $0.93 \pm 0.01$ \\
Ramanathan et al. (2001) & January-March 2001 & $0.88 \pm 0.01$ \\
\hline Arabian Sea & & \\
\hline Present study & April-May 2006 & $0.94 \pm 0.01$ \\
Kedia et al. (2010) & April-May 2006 & $0.96 \pm 0.01$ \\
Ramanathan et al. (2001) & January-March 1999 & $0.89 \pm 0.02$ \\
Ramachandran and Jayaraman (2002) & January-March 1999 & $0.87 \pm 0.05$ \\
\hline
\end{tabular}

found to be $-4.7,-11.3$, and $+6.6 \mathrm{~W} \mathrm{~m} \mathrm{~m}^{-2}$ at TOA, SUR, and ATM, while that over AS was $-6.1,-10.7$, and $+4.6 \mathrm{~W} \mathrm{~m}^{-2}$ at TOA, SUR, and ATM (Table S4). The model-simulated regional-seasonal mean DARF was compared to the DARF sampled along the ship track to analyse to which extent the ICARB cruise was representative of the entire region/premonsoon season. The regional-seasonal mean simulated DARF over the $\mathrm{BoB}$ was $-4.2 \mathrm{~W} \mathrm{~m}^{-2},-9.8 \mathrm{~W} \mathrm{~m}^{-2}$, and 
Table 7. Mean clear-sky short-wave direct aerosol radiative forcing (DARF, $\mathrm{W} \mathrm{m}^{-2}$ ) at the top of the atmosphere (TOA), at the surface (SUR), and within the atmosphere (ATM) over the Bay of Bengal and Arabian Sea regions during ICARB obtained from present study in comparison with earlier studies.

\begin{tabular}{|c|c|c|c|c|c|c|c|c|c|c|c|c|}
\hline \multirow[t]{2}{*}{ Region } & \multicolumn{3}{|c|}{$\begin{array}{l}\text { HAM DARF } \\
\left(\mathrm{W} \mathrm{m}^{-2}\right)\end{array}$} & \multicolumn{3}{|c|}{$\begin{array}{l}\text { Sunphotometer tied } \\
\text { DARF }\left(\mathrm{W} \mathrm{m}^{-2}\right)\end{array}$} & \multicolumn{3}{|c|}{$\begin{array}{l}\text { Satellite tied DARF } \\
\qquad\left(\mathrm{W} \mathrm{m}^{-2}\right)\end{array}$} & \multicolumn{3}{|c|}{$\begin{array}{l}\text { ICARB DARF }\left(\mathrm{W} \mathrm{m}^{-2}\right) \\
\text { from Kedia et al. }(2010)\end{array}$} \\
\hline & TOA & SUR & ATM & TOA & SUR & ATM & TOA & SUR & ATM & TOA & SUR & ATM \\
\hline Total & -5.5 & -12.1 & 6.6 & -8.7 & -19.9 & 11.1 & -7.8 & -17.8 & 9.9 & & & \\
\hline Bay of Bengal & -5 & -12.6 & 7.6 & -9.8 & -24.3 & 14.5 & -8.6 & -21.4 & 12.9 & -12 & -22.4 & 10.4 \\
\hline Arabian Sea & -6.2 & -11.5 & 5.4 & -7.4 & -13.9 & 6.6 & -6.8 & -12.8 & 6 & -10.5 & -15.8 & 5.3 \\
\hline
\end{tabular}

$+5.6 \mathrm{~W} \mathrm{~m}^{-2}$ at TOA, SUR, and ATM, respectively; and -6.0, -10.7 , and $+4.7 \mathrm{~W} \mathrm{~m}^{-2}$ over the AS leg. On average, thus, the forcings sampled along the ship track were consistent with the ones obtained for the entire region and premonsoon season to within $\pm 0.5 \mathrm{~W} \mathrm{~m}^{-2}, \pm 1.5 \mathrm{~W} \mathrm{~m}^{-2}$ and $\pm 1 \mathrm{~W} \mathrm{~m}^{-2}$ at TOA, SUR, and ATM, respectively, with much less discrepancy over the AS than over the BoB. Since the regional-seasonal mean DARF sampled along the ICARB ship track corresponds so well to the temporal and seasonal mean DARF over the BoB and, even more so, AS regions, we conclude that the ICARB cruise track was well chosen to be representative of the entire region and the season.

Above, we showed that the model was underestimating AOD values, especially for dust and in high pollution episodes. Thus, the simulated DARF was likely to be underestimated as well. We thus use the observations to obtain constrained, improved DARF estimates. A satellite-tied DARF was calculated by multiplying model-simulated seasonal mean forcing efficiency (DARF per unit AOD) with MODIS AOD. A sunphotometer-tied DARF was calculated also, by multiplying the simulated seasonal mean forcing efficiency with the ICARB ship-based AOD along the ship track (Table 7). As expected, the forcing increases in absolute terms, particularly over the BoB, where observed AODs were larger than the simulated ones. Sunphotometer-tied forcings along the cruise track were somewhat larger than satellite-tied ones, consistent with what we found earlier from the model. This forcing estimate, revised using the observations, yields a seasonal mean forcing of -9.8 and $-24.3 \mathrm{~W} \mathrm{~m}^{-2}$ at the TOA and at the surface (Table 7). The unconstrained model estimated forcing underestimated the TOA and surface forcing by a factor of 1.4. This indicates that the magnitude of model uncertainty in the estimation of aerosol radiative forcing. As a best estimate, the regionalmean seasonal-mean forcing, as obtained by the satellitetied computation, in the BoB region is $-8.6,-21.4$, and $+12.9 \mathrm{~W} \mathrm{~m}^{-2}$ at TOA, SUR, and ATM, respectively, and in the AS region, $-6.8,-12.8$, and $+6.0 \mathrm{~W} \mathrm{~m}^{-2}$ at TOA, SUR, and ATM, respectively (Table 7). The forcing along the track can be compared to the published values for the ICARB campaign from Kedia et al. (2010), which we list in Table 7. The sunphotometer-tied values were much closer - within about $\pm 2 \mathrm{~W} \mathrm{~m}^{-2}$, except for the ATM forcing over the BoB, where the discrepancy was $4 \mathrm{~W} \mathrm{~m}^{-2}$ - to the Kedia et al. (2010) obtained than the model-only estimates.

The spatial variations of the seasonal-mean DARF, as obtained by the satellite-tied computation, at TOA, SUR and ATM during the ICARB period are shown in Fig. 7. Large spatial heterogeneity in DARF was observed in both BoB and $A S$ regions consistent with AOD patterns over both regions. Over the BoB region, the atmospheric forcing was found to be high when the ship was moving near the northern BoB, while over AS the forcing was high when the ship was moving near the southern Indian peninsula. This was consistent with the ICARB cruise observations (Kedia et al., 2010; Moorthy et al., 2009). The TOA forcing was negative over most of oceanic regions except over regions with bright surfaces (desert and ice regions). Significant cooling was simulated at the TOA $\left(-2\right.$ to $\left.-10 \mathrm{~W} \mathrm{~m}^{-2}\right)$ and at the SUR $\left(-5\right.$ to $\left.-25 \mathrm{~W} \mathrm{~m}^{-2}\right)$ over the BoB and AS regions, which compares well with previous GCM estimates (Reddy et al., 2004). The ATM forcing decreased continuously with latitude from $\geq 15 \mathrm{~W} \mathrm{~m}^{-2}$ to $5 \mathrm{~W} \mathrm{~m}^{-2}$ as was reported in ICARB cruise studies (Moorthy et al., 2009).

The aerosol radiative forcing efficiency (ARFE, $\left.\mathrm{W} \mathrm{m}{ }^{-2} \tau^{-1}\right)$ is defined as the direct $\operatorname{ARF}\left(\mathrm{W} \mathrm{m}^{-2}\right)$ per unit $\mathrm{AOD}$ at $550 \mathrm{~nm}$. It isolates the influences of aerosol particle properties on radiation from AOD and indicates the sensitivity of direct ARF to AOD. The ARFE value determines the efficiency of the aerosols to interact with the radiation and indicates the aerosol type and its absorption efficiency (Moorthy et al., 2009). In this study, the spatial distribution of ARFE within the atmosphere was examined to understand the efficiency of BoB and AS aerosols in forcing the atmosphere during pre-monsoon season (Fig. 7d). The aerosols capable of imparting higher ATM forcing were located in the IGP, central India, eastern India and east Asia regions (Fig. 7d). Interestingly over coastal regions which are rich in aerosols, only northern BoB, northwestern AS and southern BoB regions were found to have high atmospheric absorption efficiency indicating that the presence of more absorbing type (BC and dust) aerosols. High AOD 

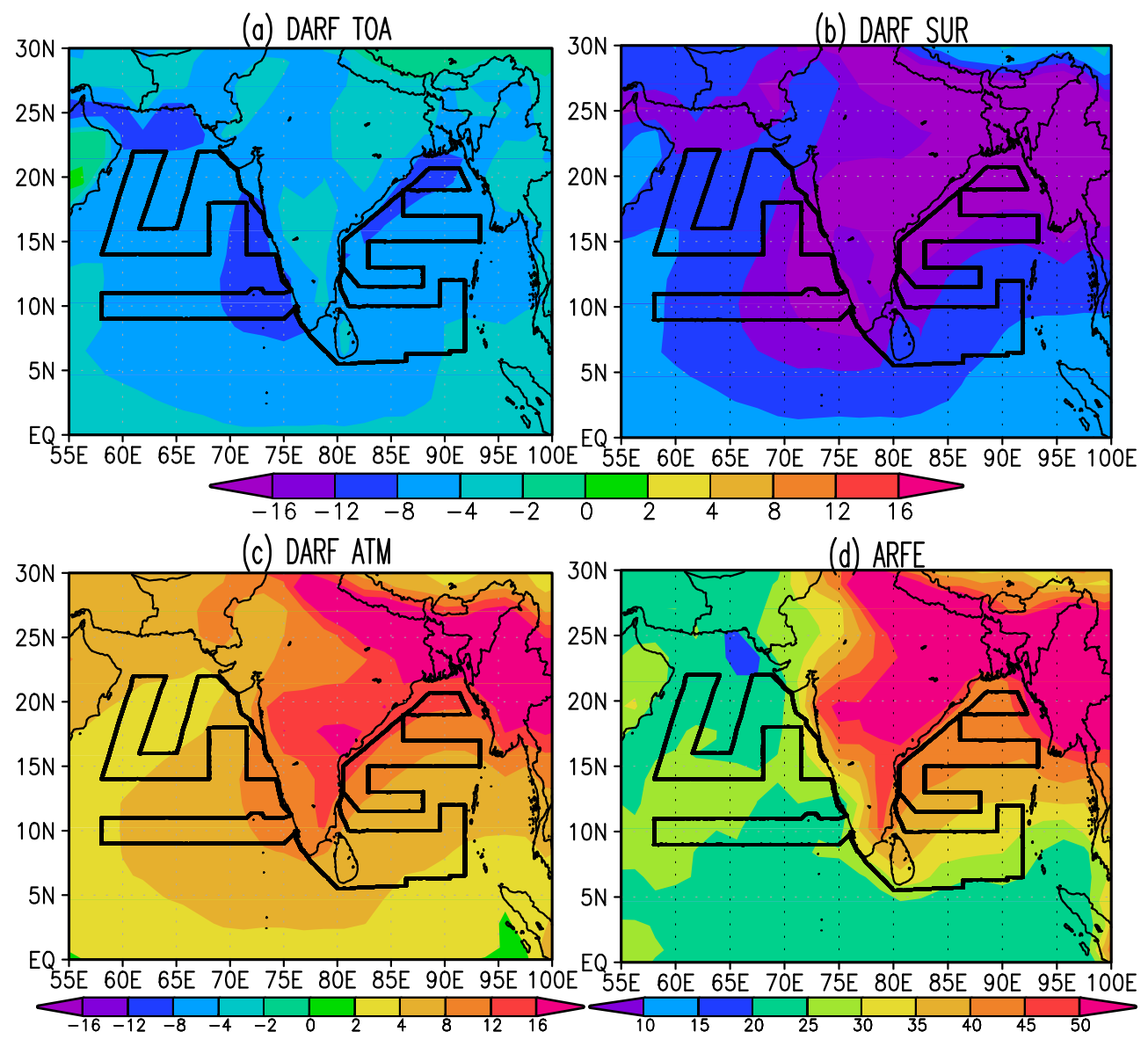

Fig. 7. Spatial distribution of clear-sky shortwave (SW) DARF $\left(\mathrm{W} \mathrm{m}^{-2}\right)$ at the (a) top of the atmosphere (TOA), (b) surface (SUR), (c) within the atmosphere (ATM) and (d) atmospheric forcing efficiency (ARFE, $\mathrm{W} \mathrm{m}^{-2} \tau^{-1}$ ).

regions such as off the coast of Mangalore show low forcing efficiency implying the presence of more scattering type aerosols (mainly sulfates).

The seasonal mean ARFE at TOA, surface and atmosphere was compared against the measurement based ARFE reported by Moorthy et al. (2009). The model-simulated ARFE agrees reasonably well with reported mean forcing efficiency at TOA and surface (Moorthy et al., 2009) over $\mathrm{BoB}$ and AS during ICARB (Table 8). The significantly smaller $\left(\sim 8 \mathrm{~W} \mathrm{~m}^{-2} \tau^{-1}\right)$ atmospheric forcing efficiency over the AS compared to BoB seen in our study can be attributed to the large decrease in the $\mathrm{BC}$ aerosols over AS during the pre-monsoon season. The model-simulated ARFE over AS is significantly higher $\left(\sim 11 \mathrm{~W} \mathrm{~m}^{-2} \tau^{-1}\right)$ than the reported values during ICARB cruise period (Moorthy et al., 2009). This is attributed to the high abundance of mineral dust transported in the model from arid regions lying to the west Asian regions. The net atmospheric forcing efficiency is found to increase significantly when there were dust transports from west Asian regions. The mean atmospheric forcing efficiency $\left(29 \pm 4 \mathrm{~W} \mathrm{~m}^{-2} \tau^{-1}\right)$ over the AS is considerably lower than the values reported $\left(50 \mathrm{~W} \mathrm{~m}^{-2} \tau^{-1}\right)$ during INDOEX (Ramanathan et al., 2001) indicate that the significant changes in dust aerosols (atmospheric absorption, see Fig. 7) during pre-monsoon season.

The ratio $\left(f_{\mathrm{s}}\right)$ of the surface forcing to the TOA forcing gives an indication to the aerosol type (scattering or absorbing). Generally the values of $f_{\mathrm{s}}>\sim 3$ represent strong influence of absorbing aerosols while for scattering aerosols $f_{\mathrm{s}}<2$ (Podgorny et al., 2000). The ratio ranges from 2 to 3 over the BoB and 1 to 2 over the AS, which compares well (2 to 3) with the previous estimates (Moorthy et al., 2009) and reveals the dominance of the surface forcing and scattering aerosols (sulfates, organic carbon, and sea salt) over most of the oceanic regions. High $f_{\mathrm{s}}$ values $(>5)$ found over the polluted regions (northeastern India and east Asia regions) indicate the dominance of absorbing aerosols, which mainly resulted from biomass burning and forest burning.

In this study, we examined how representative are the DARF estimates simulated by the model for the multiyear pre-monsoon season over the BoB and AS regions. The five year (2001-2005) model-simulated clear-sky short-wave 
Table 8. Inter comparison of mean aerosol radiative forcing efficiency (ARFE) at the top-of-the-atmosphere (TOA), surface (SUR) and within the atmosphere (ATM) during ICARB campaign.

\begin{tabular}{|c|c|c|c|c|c|c|}
\hline \multirow{3}{*}{ Region } & \multicolumn{6}{|c|}{ Aerosol radiative forcing efficiency $\left(\operatorname{ARFE}\left(\mathrm{W} \mathrm{m}^{-2} \tau^{-1}\right)\right)$} \\
\hline & \multicolumn{2}{|c|}{ TOA } & \multicolumn{2}{|c|}{ SUR } & \multicolumn{2}{|c|}{ ATM } \\
\hline & $\begin{array}{r}\text { Present } \\
\text { study }\end{array}$ & $\begin{array}{l}\text { Moorthy et } \\
\text { al. (2009) }\end{array}$ & $\begin{array}{r}\text { Present } \\
\text { study }\end{array}$ & $\begin{array}{l}\text { Moorthy et } \\
\text { al. (2009) }\end{array}$ & $\begin{array}{r}\text { Present } \\
\text { study }\end{array}$ & $\begin{array}{l}\text { Moorthy et } \\
\text { al. (2009) }\end{array}$ \\
\hline Bay of Bengal & $-31.95 \pm 4$ & $-30 \pm 3$ & $-68 \pm 6$ & $-61 \pm 5$ & $37 \pm 3$ & $31 \pm 6$ \\
\hline Arabian Sea & $-34.7 \pm 4$ & $-35 \pm 3$ & $-64 \pm 8$ & $-53 \pm 5$ & $29 \pm 4$ & $18 \pm 7$ \\
\hline
\end{tabular}

Table 9. Comparison of model-simulated multi-year mean all-sky aerosol radiative forcing and reported all-sky forcing from Satheesh et al. (2006) over northern and southern BoB and AS regions.

\begin{tabular}{|c|c|c|c|c|}
\hline \multirow{2}{*}{ Region } & \multicolumn{2}{|c|}{ Surface } & \multicolumn{2}{|c|}{ Atmosphere } \\
\hline & $\begin{array}{r}\text { Present study } \\
\text { (Mar-May } \\
2001-2006)\end{array}$ & $\begin{array}{r}\text { Satheesh et al. } \\
(2006) \\
(2000-2004)\end{array}$ & $\begin{array}{r}\text { Present study } \\
\text { (Mar-May } \\
\text { 2001-2006) }\end{array}$ & $\begin{array}{r}\text { Satheesh et al. } \\
(2006) \\
(2000-2004)\end{array}$ \\
\hline Northern BoB & $-16.4 \pm 6$ & -9 to -30 & $18.3 \pm 3.4$ & 6 to 20 \\
\hline Southern BoB & $-9.6 \pm 2$ & -3 to -12 & $7 \pm 3$ & 1 to 6 \\
\hline Northern AS & $-15 \pm 5$ & -12 to -18 & $9 \pm 4$ & 6 to 15 \\
\hline Southern AS & $-10 \pm 3$ & -3 to -6 & $5 \pm 2$ & 1 to 3 \\
\hline
\end{tabular}

satellite-tied DARF is used for this analysis. The modelsimulated multiyear (2001-2005) seasonal-mean satellitetied DARF is compared with satellite-tied DARF during ICARB over the BoB and AS regions (Table S5). The DARF during ICARB captured statistically well with the multiyear satellite-tied DARF values and with the available radiative forcing estimates from previous studies (Table S5) indicate that the regional forcing estimates from this study well represents the multiyear pre-monsoon season. The importance of the findings from this study are that (1) more robust (measurement constrained) estimates of regionally and seasonally representative aerosol radiative forcing over $\mathrm{BoB}$ and $\mathrm{AS}$ from climate models, and (2) the mean forcing efficiency of the $\mathrm{BoB}$ and AS broadly agree the regional/seasonal mean values reported from previous multiyear studies, implying that aerosol forcing inter-annual variability for this oceanic region and season was low at temporal scales, and at horizontal space scales of less than 1 degree. However, the observed large spatial and temporal (episode wise) heterogeneities in aerosol properties and their radiative effects needs to be better understood over $\mathrm{BoB}$ and $\mathrm{AS}$ regions by integrating measurements with climate models.

Multiyear (2001-2006) mean model-simulated all-sky aerosol radiative forcing values were compared with reported multi-year (2000-2004) forcing estimates (Satheesh et al., 2006) to understand the regional differences within the BoB and AS regions (Table 9). The mean all-sky aerosol surface radiative forcing over northern $\mathrm{BoB}$ and $\mathrm{AS}(-16.4$ to $-15 \mathrm{~W} \mathrm{~m}^{-2}$ ) were larger compared to that over southern BoB and AS $\left(-10 \mathrm{~W} \mathrm{~m}^{-2}\right)$. The mean all-sky forcing simulated by the model is consistent with the reported all-sky forcing values over the northern and southern BoB. A larger difference in surface cooling over southern AS was found between modelled and reported all-sky forcings. This difference can be attributed to the differences in cloud fraction used in both the estimations.

\section{Conclusions}

This study analyses ship-based sun-photometer measurements of aerosol optical properties and their direct radiative effects from the ICARB field campaign over the BoB and the AS region together with a nudged simulation of the largescale aerosol-climate model ECHAM5.5-HAM and several satellite data sets. The regional-seasonal representativeness of the aerosol properties was investigated through observations and model predictions at point locations along the ship track and over the entire region during the pre-monsoon season. The statistical comparison of the model predictions with the ship-based observations and large-scale climatology from satellite observations shows that aerosol properties simulated by the model is reasonably well representative of the aerosol climatology over the northern Indian Ocean and the pre-monsoon season. 
The large spatial and temporal heterogeneities of AOD observed from ships and satellites (MODIS and OMI) measurements during ICARB are reasonably well simulated by the model. Simulated AOD variability agrees rather well with both in-situ and satellite observations $(R=0.77$ to 0.88$)$ during AS legs. However, the model grossly underestimates (by a factor of 3) the large AODs observed during high pollution days, especially over the BoB legs. Since MODIS retrievals of AOD correspond well to the ship-based sunphotometer measurements, and since also the sparse sampling of MODIS (up to twice daily, depending on cloudiness) agrees well with the diurnal averages of the ship-based observations, we conclude that the AOD variability for this oceanic region and season was low at temporal scales of less than 1 day, and at horizontal space scales of less than 1 degree. The HAM simulated AOD agrees better with the ship-based sunphotometer measurements and satellite measurements during cloud-free days when compared to all days indicating enhanced spatio-temporal AOD variability because of aerosol swelling resulted from larger humidity and/or retrieval errors in cloudy situations.

HAM simulated fine and coarse mode AODs at $550 \mathrm{~nm}$ were evaluated with MODIS retrievals to better understand the model performance over the BoB and AS legs. The HAM fine mode AODs were underpredicted by a factor of 2 as compared to satellite observations, while coarse mode AODs were strongly underestimated by a factor of 3 to 6 over the $\mathrm{BoB}$ region. The analysis of dust AOD along with the UV AI from OMI sensor found that the model is unable to capture high AODs, traced back to dust transport, which we concluded to result from the too low model-simulated dust emission flux over the Thar Desert (north-west India) region. This caused an underestimation of coarse mode AODs over BoB regions. The fine and coarse mode AODs were predicted better over the AS region except for a few days where the model wind fields transported fine and coarse mode aerosols from west Asia, and central and southern India to the surrounding oceanic regions. In these cases, a significant underestimation of super-micron dust AODs resulted in the underestimation of AODs in high pollution days over the BoB legs.

Aerosol direct radiative forcing exhibits large spatial heterogeneities over the $\mathrm{BoB}$ and AS regions. The regionalseasonal mean clear-sky shortwave DARF was found to correspond well to DARF sampled along ship cruise track over the $\mathrm{BoB}$ and $\mathrm{AS}$ regions. In conclusion, the ICARB cruise was well chosen to be representative of direct aerosol radiative effects for the entire region and the season. Taking into account the model deficiencies (underprediction of AOD) by constraining radiative effect computations with observations, the mean DARF over the BoB is $-8.6,-21.4$ and $+12.9 \mathrm{~W} \mathrm{~m}^{-2}$ at TOA, SUR, and ATM, and over the AS, $-6.8,-12.8$, and +6 at TOA, SUR, and ATM, respectively. The spatial heterogeneity of aerosol radiative forcing resembles that of the AOD; while the spatial variability of atmospheric forcing efficiency was similar to that of the AAOD. This study provides a robust (measurement constrained) knowledge of the regionally and seasonally representative clear-sky aerosol radiative forcing over $\mathrm{BoB}$ and AS region.

\section{Supplementary material related to this article is available online at: http://www.atmos-chem-phys.net/12/1287/2012/ acp-12-1287-2012-supplement.pdf.}

Acknowledgements. This work was supported through the Atmospheric Trace Gases-Chemistry, Transport and Modeling (AT-CTM) project of the Indian Space Research Organisation's Geosphere Biosphere Programme (ISRO-GBP), Bengaluru, India. The satellite data used in this study are downloaded from GES-DISC, NASA. Computing time was provided by the German High Performance Computing Centre for Climate and Earth System Research (Deutsches Klimarechenzentrum, DKRZ). We thank Kai Zhang (Max Planck Institute for Meteorology) for carefully reviewing the manuscript. J. Quaas was supported by an Emmy Noether grant of the German Research Foundation (DFG). Ribu Cherian acknowledges the funding support from the Guest-Exchange program of the International Max Planck Research School on Earth System Modelling (IMPRS-ESM) for his visit to MPI-M (Hamburg, Germany).

The service charges for this open access publication have been covered by the Max Planck Society.

Edited by: E. Vignati

\section{References}

Adhikary, B., Carmichael, G. R., Tang, Y., Leung, L. R., Qian, Y., Schauer, J. J., Stone, E. A., Ramanathan, V., and Ramana, M. V.: Characterization of the seasonal cycle of south asian aerosols: A regional-scale modeling analysis, J. Geophys. Res., 112, D22S22, doi:10.1029/2006JD008143, 2007.

Andres, R. J. and Kasgnoc, A. D.: A time-averaged inventory of subaerial volcanic sulfur emissions, J. Geophys. Res., 103, 25251-25261, 1998.

Bellouin, N., Boucher, O., Vesperini, M., and Tanre, D.: Estimating the direct aerosol radiative perturbation: Impact of ocean surface representation and aerosol non-sphericity, Q. J. Roy. Meteorol. Soc., 130, 2217-2232, doi:10.1256/qj.03.136, 2004.

Bian, H., Chin, M., Rodriguez, J. M., Yu, H., Penner, J. E., and Strahan, S.: Sensitivity of aerosol optical thickness and aerosol direct radiative effect to relative humidity, Atmos. Chem. Phys., 9, 2375-2386, doi:10.5194/acp-9-2375-2009, 2009.

Bonazzola, M., Picon, L., Laurent, H., Hourdin, F., Sèze, G., Pawlowska, H., and Sadourny, R.: Retrieval of large-scale wind divergences from infrared meteosat- 5 brightness temperatures over the indian ocean, J. Geophys. Res., 106, 28113-28128, 2001.

Cheng, T., Peng, Y., Feichter, J., and Tegen, I.: An improvement on the dust emission scheme in the global aerosol-climate model ECHAM5-HAM, Atmos. Chem. Phys., 8, 1105-1117, doi:10.5194/acp-8-1105-2008, 2008. 
Cherian, R., Venkataraman, C., Kumar, A., Sarin, M. M., Sudheer, A. K., and Ramachandran, S.: Source identification of aerosols influencing atmospheric extinction: Integrating pmf and pscf with emission inventories and satellite observations, J. Geophys. Res., 115, D22212, doi:10.1029/2009JD012975, 2010.

Chung, C. E., Ramanathan, V., Kim, D., and Podgorny, I. A.: Global anthropogenic aerosol direct forcing derived from satellite and ground-based observations, J. Geophys. Res., 110, D24207, doi:10.1029/2005JD006356, 2005.

Cofala, J., Amann, M., and Mechler, R.: Scenarios of world anthropogenic emissions of air pollutants and methane up to 2030, International Institute for Applied Systems Analysis (IIASA)), Laxenburg, Austria, 2005.

Dentener, F., Kinne, S., Bond, T., Boucher, O., Cofala, J., Generoso, S., Ginoux, P., Gong, S., Hoelzemann, J. J., Ito, A., Marelli, L., Penner, J. E., Putaud, J.-P., Textor, C., Schulz, M., van der Werf, G. R., and Wilson, J.: Emissions of primary aerosol and precursor gases in the years 2000 and 1750 prescribed data-sets for AeroCom, Atmos. Chem. Phys., 6, 4321-4344, doi:10.5194/acp6-4321-2006, 2006.

Dey, S. and Di Girolamo, L.: A climatology of aerosol optical and microphysical properties over the indian subcontinent from 9 years (2000-2008) of multiangle imaging spectroradiometer (misr) data, J. Geophys. Res., 115, D15204, doi:10.1029/2009JD013395, 2010.

Feichter, J., Kjellstrom, E., Rodhe, H., Dentener, F., Lelieveld, J., and Roelofs, G. J.: Simulation of the tropospheric sulfur cycle in a global climate model, Atmos. Environ., 30, 1693-1707, 1996.

Flaounas, E., Coll, I., Armengaud, A., and Schmechtig, C.: The representation of dust transport and missing urban sources as major issues for the simulation of PM episodes in a Mediterranean area, Atmos. Chem. Phys., 9, 8091-8101, doi:10.5194/acp-9-80912009, 2009.

Forster, P., Ramaswamy, V., Artaxo, P., Berntsen, T., Betts, R., Fahey, D. W., Haywood, J., Lean, J., Lowe, D. C., Myhre, G., Nganga, J., Prinn, R., Raga, G., Schulz, M., and Dorland, R. V.: Changes in atmospheric constituents and in radiative forcing in: Climate change 2007: The physical science basis-contribution of working group $i$ to the fourth assessment report of the intergovernmental panel on climate change, edited by: Solomon, S., Qin, D., Manning, M., Chen, Z., Marquis, M., Averyt, K. B., Tignor, M., and Miller, H. L., Cambridge Univ. Press, Cambridge, UK, 153-171, 2007.

Grini, A., Myhre, G., Zender, C. S., and Isaksen, I. S. A.: Model simulations of dust sources and transport in the global atmosphere: Effects of soil erodibility and wind speed variability, J. Geophys. Res., 110, D02205, doi:10.1029/2004JD005037, 2005.

Haywood, J. M., Ramaswamy, V., and Donner, L. J.: A limitedarea-model case study of the effects of sub-grid scale variations in relative humidity and cloud upon the direct radiative forcing of sulfate aerosol, Geophys. Res. Lett., 24, 143-146, 1997.

Huneeus, N., Schulz, M., Balkanski, Y., Griesfeller, J., Prospero, J., Kinne, S., Bauer, S., Boucher, O., Chin, M., Dentener, F., Diehl, T., Easter, R., Fillmore, D., Ghan, S., Ginoux, P., Grini, A., Horowitz, L., Koch, D., Krol, M. C., Landing, W., Liu, X., Mahowald, N., Miller, R., Morcrette, J.-J., Myhre, G., Penner, J., Perlwitz, J., Stier, P., Takemura, T., and Zender, C. S.: Global dust model intercomparison in AeroCom phase I, Atmos. Chem. Phys., 11, 7781-7816, doi:10.5194/acp-11-7781-2011, 2011.
Jacobson, M. Z.: Strong radiative heating due to the mixing state of black carbon in atmospheric aerosols, Nature, 409, 695-697, 2001.

Kahn, R. A., Garay, M. J., Nelson, D. L., Yau, K. K., Bull, M. A., Gaitley, B. J., Martonchik, J. V., and Levy, R. C.: Satellite-derived aerosol optical depth over dark water from misr and modis: Comparisons with aeronet and implications for climatological studies, J. Geophys. Res., 112, D18205, doi:10.1029/2006JD008175, 2007.

Kedia, S. and Ramachandran, S.: Features of aerosol optical depths over the bay of bengal and the arabian sea during premonsoon season: Variabilities and anthropogenic influence, J. Geophys. Res., 113, D11201, doi:10.1029/2007JD009070, 2008.

Kedia, S., Ramachandran, S., Kumar, A., and Sarin, M. M.: Spatiotemporal gradients in aerosol radiative forcing and heating rate over bay of bengal and arabian sea derived on the basis of optical, physical, and chemical properties, J. Geophys. Res., 115, D07205, doi:10.1029/2009JD013136, 2010.

Kinne, S., Schulz, M., Textor, C., Guibert, S., Balkanski, Y., Bauer, S. E., Berntsen, T., Berglen, T. F., Boucher, O., Chin, M., Collins, W., Dentener, F., Diehl, T., Easter, R., Feichter, J., Fillmore, D., Ghan, S., Ginoux, P., Gong, S., Grini, A., Hendricks, J., Herzog, M., Horowitz, L., Isaksen, I., Iversen, T., Kirkevåg, A., Kloster, S., Koch, D., Kristjansson, J. E., Krol, M., Lauer, A., Lamarque, J. F., Lesins, G., Liu, X., Lohmann, U., Montanaro, V., Myhre, G., Penner, J., Pitari, G., Reddy, S., Seland, O., Stier, P., Takemura, T., and Tie, X.: An AeroCom initial assessment - optical properties in aerosol component modules of global models, Atmos. Chem. Phys., 6, 1815-1834, doi:10.5194/acp-6-1815-2006, 2006.

Koch, D., Bond, T. C., Streets, D., Unger, N., and van der Werf, G. R.: Global impacts of aerosols from particular source regions and sectors, J. Geophys. Res., 112, D02205, doi:10.1029/2005JD007024, 2007.

Lawrence, M. G. and Lelieveld, J.: Atmospheric pollutant outflow from southern Asia: a review, Atmos. Chem. Phys., 10, 1101711096, doi:10.5194/acp-10-11017-2010, 2010.

Moorthy, K. K. and Saha, A.: Aerosol study during indoex: Observation of enhanced aerosol activity over the mid arabian sea during the northern winter, J. Atmos. Solar-Terr. Phys., 62, 65$72,2000$.

Moorthy, K. K., Satheesh, S. K., Babu, S. S., and Dutt, C. B. S.: Integrated campaign for aerosols, gases and radiation budget (icarb): An overview, J. Earth Sys. Sci., 117, 243-262, 2008.

Moorthy, K. K., Nair, V. S., Babu, S. S., and Satheesh, S. K.: Spatial and vertical heterogeneities in aerosol properties over oceanic regions around india: Implications for radiative forcing, J. R. Meteorol. Soc., 135, 2131-2145, 2009.

Nair, V. S., Babu, S. S., and Moorthy, K. K.: Spatial distribution and spectral characteristics of aerosol single scattering albedo over the bay of bengal inferred from shipborne measurements Geophys. Res. Lett., 35, L10806, doi:10.1029/2008GL033687, 2008

Parameswaran, K., Nair, P. R., Rajan, R., and Ramana, M. V.: Aerosol loading in coastal and marine environments in the indian ocean region during winter season, Curr. Sci., 76, 947-955, 1999.

Podgorny, I. A., Conant, W., Ramanathan, V., and Satheesh, S. K.: Aerosol modulation of atmospheric and surface solar heat- 
ing over the tropical indian ocean, Tellus B, 52, 947-958, 2000. Quaas, J., Stevens, B., Stier, P., and Lohmann, U.: Interpreting the cloud cover - aerosol optical depth relationship found in satellite data using a general circulation model, Atmos. Chem. Phys., 10, 6129-6135, doi:10.5194/acp-10-6129-2010, 2010.

Ramachandran, S.: Spectral aerosol optical characteristics during the northeast monsoon over the arabian sea and the tropical indian ocean: 1. Aerosol optical depths and their variabilities, J. Geophys. Res., 109, D19207, doi:10.1029/2003JD004476, 2004.

Ramachandran, S.: Premonsoon shortwave aerosol radiative forcings over the arabian sea and tropical indian ocean: Yearly and monthly mean variabilities, J. Geophys. Res., 110, D07207, doi:10.1029/2004JD005563, 2005.

Ramachandran, S. and Cherian, R.: Regional and seasonal variations in aerosol optical characteristics and their frequency distributions over india during 2001-2005, J. Geophys. Res., 113, D08207, doi:10.1029/2007JD008560, 2008.

Ramachandran, S. and Jayaraman, A.: Premonsoon aerosol mass loadings and size distributions over the arabian sea and the tropical indian ocean, J. Geophys. Res., 107, 4738, doi:10.1029/2002JD002386, 2002.

Ramanathan, V., et al.: Indian ocean experiment: An integrated analysis of the climate forcing and effects of the great indo-asian haze, J. Geophys. Res., 106, 28371-28398, 2001.

Reddy, M. S. and Venkataraman, C.: Inventory of aerosol and sulphur dioxide emissions from india: I - fossil fuel combustion, Atmos. Environ., 36, 677-697, 2002.

Reddy, M. S., Boucher, O., Venkataraman, C., Verma, S., Leon, J. F., Bellouin, N., and Pham, M.: General circulation model estimates of aerosol transport and radiative forcing during the indian ocean experiment, J. Geophys. Res., 109, D16205, doi:10.1029/2004JD004557, 2004.

Reddy, M. S., Boucher, O., Balkanski, Y., and Schulz, M.: Aerosol optical depths and direct radiative perturbations by species and source type, Geophys. Res. Lett., 32, L12803, doi:10.1029/2004GL021743, 2005.

Remer, L. A., Kaufman, Y. J., Tanre, D., Mattoo, S., Chu, D. A., Martins, J. V., Li, R. R., Ichoku, C., Levy, R. C., Kleidman, R. G., Eck, T. F., Vermote, E., and Holben, B. N.: The modis aerosol algorithm, products, and validation, J. Atmos. Sci., 62, 947-973, 2005.

Roeckner, E.: The atmospheric general circulation model echam5. Part i: Model description, Max Planck Institute for Meteorology, Hamburg, Germany, 349, 1-140, 2003.

Satheesh, S. K., Srinivasan, J., and Moorthy, K. K.: Spatial and temporal heterogeneity in aerosol properties and radiative forcing over bay of bengal: Sources and role of aerosol transport, J. Geophys. Res., 111, D08202, doi:10.1029/2005JD006374, 2006.

Schulz, M., G., Leeuw, D., and Balkanski, Y.: Emission of atmospheric trace compounds, Chap. Sea-salt aerosol source functions and emissions, edited by: Kluwer, 333-359, 2004.

Simmons, A. J. and Gibson, J. K.: The era-40 project plan, era-40 project report series 1, ECMWF, Shinfield Park, Reading, UK, 2000.

Stier, P., Feichter, J., Kinne, S., Kloster, S., Vignati, E., Wilson, J., Ganzeveld, L., Tegen, I., Werner, M., Balkanski, Y., Schulz, M., Boucher, O., Minikin, A., and Petzold, A.: The aerosolclimate model ECHAM5-HAM, Atmos. Chem. Phys., 5, 1125 1156, doi:10.5194/acp-5-1125-2005, 2005.
Stier, P., Feichter, J., Kloster, S., Vignati, E., and Wilson, J.: Emission-induced nonlinearities in the global aerosol system: Results from the echam5-ham aerosol-climate model, J. Climate., 19, 3845-3862, 2006.

Stier, P., Seinfeld, J. H., Kinne, S., and Boucher, O.: Aerosol absorption and radiative forcing, Atmos. Chem. Phys., 7, 52375261, doi:10.5194/acp-7-5237-2007, 2007.

Tegen, I., Harrison, S. P., Kohfeld, K., Prentice, I. C., Coe, M., and Heimann, M.: Impact of vegetation and preferential source areas on global dust aerosol: Results from a model study, J. Geophys. Res., 107, 4576, doi:10.1029/2001JD000963, 2002.

Textor, C., Schulz, M., Guibert, S., Kinne, S., Balkanski, Y., Bauer, S., Berntsen, T., Berglen, T., Boucher, O., Chin, M., Dentener, F., Diehl, T., Easter, R., Feichter, H., Fillmore, D., Ghan, S., Ginoux, P., Gong, S., Grini, A., Hendricks, J., Horowitz, L., Huang, P., Isaksen, I., Iversen, I., Kloster, S., Koch, D., Kirkevåg, A., Kristjansson, J. E., Krol, M., Lauer, A., Lamarque, J. F., Liu, X., Montanaro, V., Myhre, G., Penner, J., Pitari, G., Reddy, S., Seland, Ø., Stier, P., Takemura, T., and Tie, X.: Analysis and quantification of the diversities of aerosol life cycles within AeroCom, Atmos. Chem. Phys., 6, 1777-1813, doi:10.5194/acp-61777-2006, 2006.

Toon, O. B. and Ackerman, T. P.: Algorithms for the calculation of scattering by stratified spheres, Appl. Opt., 20, 3657-3660, 1981.

Torres, O., Tanskanen, A., Veihelmann, B., Ahn, C., Braak, R., Bhartia, P. K., Veefkind, P., and Levelt, P.: Aerosols and surface uv products from ozone monitoring instrument observations: An overview, J. Geophys. Res., 112, D24S47, doi:10.1029/2007JD008809, 2007.

Venkataraman, C., Habib, G., Eiguren-Fernandez, A., Miguel, A. H., and Friedlander, S. K.: Residential biofuels in south asia: Carbonaceous aerosol emissions and climate impacts, Science, 307, 1454-1456, 2005.

Venkataraman, C., Habib, G., Kadamba, D., Shrivastava, M., Leon, J. F., Crouzille, B., Boucher, O., and Streets, D. G.: Emissions from open biomass burning in india: Integrating the inventory approach with high-resolution moderate resolution imaging spectroradiometer (modis) active-fire and land cover data, Global Biogeochem. Cy., 20, GB2013, doi:10.1029/2005GB002547, 2006.

Verma, S., Venkataraman, C., and Boucher, O.: Origin of surface and columnar indian ocean experiment (indoex) aerosols using source- and region-tagged emissions transport in a general circulation model, J. Geophys. Res., 113, D24211, doi:10.1029/2007JD009538, 2008.

Vignati, E., Wilson, J., and Stier, P.: M7: An efficient size-resolved aerosol microphysics module for large-scale aerosol transport models, J. Geophys. Res., 109, D22202, doi:10.1029/2003JD004485, 2004.

Vinoj, V., Babu, S. S., Satheesh, S. K., Moorthy, K. K., and Kaufman, Y. J.: Radiative forcing by aerosols over the bay of bengal region derived from shipborne, island-based, and satellite (moderate-resolution imaging spectroradiometer) observations, J. Geophys. Res., 109, D05203, doi:10.1029/2003JD004329, 2004. 